\title{
Information Environment and the Investment Decisions of Multinational Corporations
}

\section{Citation}

Shroff, Nemit O., Rodrigo S. Verdi, and Gwen Yu. "Information Environment and the Investment Decisions of Multinational Corporations." Accounting Review 89, no. 2 (March 2014).

\section{Published Version}

http://aaajournals.org/doi/abs/10.2308/accr-50643

\section{Permanent link}

http://nrs.harvard.edu/urn-3:HUL.InstRepos:16388192

\section{Terms of Use}

This article was downloaded from Harvard University's DASH repository, and is made available under the terms and conditions applicable to Open Access Policy Articles, as set forth at http:// nrs.harvard.edu/urn-3:HUL.InstRepos:dash.current.terms-of-use\#OAP

\section{Share Your Story}

The Harvard community has made this article openly available.

Please share how this access benefits you. Submit a story.

Accessibility 


\title{
Information Environment and the Investment Decisions of Multinational Corporations
}

\author{
Nemit Shroff \\ Massachusetts Institute of Technology \\ $\underline{\text { shroff@,mit.edu }}$ \\ Rodrigo S. Verdi \\ Massachusetts Institute of Technology \\ rverdi@mit.edu \\ Gwen Yu \\ Harvard Business School \\ gyu@hbs.edu
}

Forthcoming at The Accounting Review

September, 2013

\begin{abstract}
This paper examines how the external information environment in which foreign subsidiaries operate affects the investment decisions of multinational corporations (MNCs). We hypothesize and find that the investment decisions of foreign subsidiaries in country-industries with more transparent information environments are more responsive to local growth opportunities than are those of foreign subsidiaries in country-industries with less transparent information environments. Further, this effect is larger when (i) there are greater cross-border frictions between the parent and subsidiary, and (ii) the parents are relatively more involved in their subsidiaries' investment decision-making process. Our results suggest that the external information environment helps mitigate the agency problems that arise when firms expand their operations across borders. This paper contributes to the literature by showing that the external information environment helps MNCs mitigate information frictions within the firm.
\end{abstract}

Keywords: Investment; Capital budgeting; Multinational firms; Cross-border frictions; Agency frictions; Transparency; Financial Reporting Quality; Information Quality.

JEL Classification: D83; G31; M41.

Data availability: Data are available from public sources identified in the paper.

We appreciate comments from Harry Evans (senior editor), Mort Pincus (editor), two anonymous referees, Karthik Balakrishnan (discussant), Beth Blankespoor, Brad Badertscher, John Core, Kevin Crosbie (from RavenPack), Srikant Datar, Ilia Dichev, Fritz Foley, Michelle Hanlon, Bob Kaplan, Russ Lundholm, Greg Miller, Jeff Ng, Krishna Palepu, Karthik Ramanna, Sugata Roychowdhury, Tatiana Sandino, Jayanthi Sunder (discussant), Karen Ton (discussant), Joe Weber, Hal White, seminar participants at the 2012 AAA conference, Harvard Business School 2011 IMO conference, 2012 FARS conference, 2012 FEA conference, 2012 ISB conference, Purdue University, 2011 Toronto Accounting Research Conference, the University of Oregon, and a PhD workshop at MIT. We also thank Patricia Naranjo for the excellent research assistance. We acknowledge financial support from the Division of Research at the Harvard Business School and the MIT Junior Faculty Research Assistance Program. We thank RavenPack for generously sharing the data on worldwide press coverage. All errors are our own. 


\section{INTRODUCTION}

This paper studies the role of the information environment in helping multinational corporations (MNCs) monitor and evaluate their subsidiaries' investment decisions. ${ }^{1}$ Prior research emphasizes that cross-border frictions increase information asymmetry between parents and their subsidiaries, which increases the cost of monitoring within MNCs. For example, crossborder frictions such as geographic and cultural differences make it difficult for parents to incentivize the subsidiary managers and to evaluate their actions (Roth and O'Donnell 1996). As a result, prior studies find that MNCs adjust their ownership structure, compensation contracts, and organizational design to mitigate these frictions (Desai et al. 2004; Antras et al. 2009; Siegel and Larson 2009). Despite empirical evidence of such "internal mechanisms" intended to mitigate cross-border frictions, substantial cross-sectional variation still exists in the efficiency of MNCs (Caves 2007), suggesting that these internal solutions are unlikely to fully resolve all information problems. Our paper builds on this literature by examining whether the external information environment serves as another mechanism for parents to monitor their subsidiaries' decisions and to deal with the information frictions within the firm.

The intuition for our hypothesis is that external information, such as that generated by other firms in the industry or by capital market participants, can be used to evaluate managerial actions. For example, Holmstrom (1979) shows that information disclosed by competitors and other related firms can be used to benchmark managers in relative performance compensation contracts. Holmstrom and Tirole (1993) show that external information aggregated in stock prices can be used as a monitoring mechanism to reduce agency problems, which can affect firm performance. Similarly, Bushman and Smith (2001) and Armstrong et al. (2010) discuss several cases in which external information is used to facilitate internal governance mechanisms that

\footnotetext{
${ }^{1}$ Throughout the paper, we use the terms "MNCs" and "parents" interchangeably.
} 
monitor and evaluate managers. Here again, the intuition is that external information complements internal governance systems when resolving agency problems.

We use the insights developed in the above literatures to study the role the external information environment plays in helping MNCs monitor a foreign subsidiary's investment decisions. We focus on investment because it is one of the most important managerial actions and the decision is observable. The external information environment refers to the quality and quantity of information produced by related firms, such as competitors and supply chain partners, and by information intermediaries, such as analysts and the business press, in the environment in which the subsidiary operates. The basic idea is that MNCs can use the information available in the subsidiary's operating environment to forecast product demand, evaluate the extent of competition, analyze the profitability and investment plans of direct competitors, etc. This information can then be used by MNCs to monitor and evaluate the subsidiary's investment decisions. As a result, we hypothesize that the investment decisions of subsidiaries located in rich information environments are more efficient than those of subsidiaries located in poor information environments. An implicit assumption underlying our prediction is that parents are involved in their subsidiaries' decision making process either directly by participating in the decision process or indirectly by monitoring and evaluating their decisions. We explore this assumption in greater detail in our cross-sectional tests described below.

Our analyses exploit a novel dataset provided by ORBIS, which contains detailed information on the ownership structure of subsidiaries within MNCs. Our sample consists of 6,298 unique foreign subsidiaries with 2,249 parent firms operating in 63 countries from 2000 to 2009, yielding 32,163 subsidiary-year observations. Following Wurgler (2000), Bekaert et al. (2007), and Badertscher et al. (2013), we focus on the sensitivity of a subsidiary's investment to 
its growth opportunities. Prior research interprets a higher sensitivity as more desirable based on the idea that investment is more responsive to growth opportunities when the adjustment costs, such as information frictions and agency problems, are low (Hubbard 1998). We use asset growth as a proxy for investment and the price-to-earnings (PE) ratio measured at the countryindustry level as a proxy for growth opportunities (Bekaert et al. 2007). Finally, to proxy for the quality of the external information environment, we use the median analyst coverage, press coverage, and the degree of earnings transparency by firms in the country-industry in which the subsidiary operates. These measures are extensively used as proxies for the quality of the information environment in prior research (Beyer et al. 2010). We compute these measures at the country-industry-year level to capture the external information environment. By examining the quality of the external information environment, rather than the subsidiaries' own financial reporting and disclosure quality, we mitigate the concern that the information environment and subsidiary investment are endogenously determined.

Our main specification is a subsidiary-level regression of investment on growth opportunities and an interaction between growth opportunities and the quality of the external information environment. While widely used in prior research (Hubbard 1998; Bekaert et al. 2007), this model potentially suffers from a misspecification if there is measurement error in our proxy for growth opportunity and the measurement error systematically varies with the external information environment. To mitigate this concern, we include an extensive set of control variables. Specifically, we control for differences in the sensitivity of investment to growth opportunities across countries by including country fixed effects and an interaction between each country fixed effect and growth opportunities. As a result, our identification comes from crossindustry and time variation in the information environment within each country. We also include 
parent-subsidiary country-pair fixed effects to control for bilateral relationships between the parent's and subsidiary's countries (Dellestrand and Kappen 2012), MNC fixed effects to control for differences in investment policies across MNCs (Desai et al. 2009), and controls for other internal mechanisms that mitigate agency problems within the firm, including the parent's ownership structure, internal capital markets, and reliance on domestic banking credit.

Consistent with our hypothesis, we find that the sensitivity of subsidiary investment to growth opportunities is higher in country-industries with richer information environments. In economic terms, we find a $3 \%$ difference in investment between firms in rich and poor information environments for a one standard deviation change in growth opportunities. Given that the average investment in our sample is $18 \%,{ }^{2}$ this represents a relative difference of approximately $17 \%$. These results provide initial support for our hypothesis that the information environment helps MNCs monitor and evaluate their subsidiaries' investment decisions.

Next, we perform two cross-sectional tests. First, our earlier findings suggest that the local information environment facilitates monitoring and ultimately mitigates cross-border frictions. To strengthen this result, we predict and find that the value of local information environment is greater when there are greater cross-border frictions between the parent and subsidiary, for example, when the parent and the subsidiary are located in countries that speak different languages. Second, a key assumption underlying our main hypothesis is that the parents are involved in and actively monitor their subsidiaries' investment decision. However, MNCs vary in the degree to which investment decisions are made by managers from the parent firms and, as a result, the external information environment could have a differential role depending on the parent's involvement in the decision making process. We explore this argument and find that our results are stronger when the parent is more involved in the subsidiary's investment

\footnotetext{
${ }^{2}$ Average investment is measured as the average asset growth for all subsidiaries in our sample (see Table 3).
} 
decisions, for example, when management team of the subsidiary is composed of a greater number of expatriates from the parent's country.

An important benefit of our cross-sectional test is that it exploits variation in the parent's location while holding the subsidiary's location constant. That is, we effectively compare the investment behavior of two subsidiaries located in the same country but vary in the levels of frictions between the parent and subsidiary. As a result, these tests further alleviate any concerns related to cross-country differences in the subsidiary's investing/institutional environment and measurement error in our proxies. This enhances the empirical identification of our inferences.

Finally, we perform a battery of sensitivity tests to verify the validity of our inferences. First, we use the adoption of International Financial Reporting Standards (IFRS) as a proxy for a time-series change in the quality of the external information environment (Barth et al. 2008) and find that the sensitivity of investment to growth opportunities increases for subsidiaries located in IFRS adopting countries following the mandatory adoption of IFRS. In addition, we repeat our analyses using total factor productivity as an alternative proxy for investment efficiency (Schoar 2002; Giroud 2013). Finally, in the spirit of a difference-in-difference research design, we benchmark our results for foreign subsidiaries to those for domestic subsidiaries as well as to the results for local standalone firms operating in the same country as the foreign subsidiary because these benchmark firms do not face cross-border frictions. We find that our inferences are unaffected by these additional tests.

Two important caveats regarding our dataset should be noted. First, the ORBIS dataset exhibits significant cross-country variation in subsidiary coverage, primarily due to crosscountry differences in the reporting requirements for private firms. As a result, subsidiaries in some countries are under-represented in our sample. In addition, ownership information in 
ORBIS is a stale variable, meaning that it is coded as of the latest year in the dataset. This potentially creates measurement error in our parent-subsidiary classification. We partially mitigate the influence of these database issues through our research design and sensitivity tests. Nonetheless, we acknowledge that such limitations of the ORBIS dataset may affect the generalizability of our findings.

Our paper is related to several streams of literature. First, it relates to both, the financial and managerial accounting literatures. A recent stream of papers in financial accounting investigates how information quality affects corporate investment decisions (Hope and Thomas 2008; Biddle et al. 2009; Durnev and Mangen 2009; Chen et al. 2011; Badertscher et al. 2013). A separate stream of research in managerial accounting examines the role of internal control systems, such as incentive contracts and cost accounting systems, designed to facilitate managerial decision making and reduce agency costs (Anthony 1965; Bruns and Waterhouse 1975; Datar et al. 2013). For example, Chenhall (2003) illustrates how the type of internal controls systems used in a firm largely depends on the firm's external environment. Our paper links these two literatures by investigating how the external information environment can serve as a control system that reduces information frictions within MNCs.

Second, our study also contributes to the literature in economics and international business. Prior studies examine how firms deal with agency frictions when operating across borders and find that MNCs adjust their ownership structure, compensation contracts, and organizational design to mitigate these frictions (Zaheer 1995; Smith 2001; Desai et al. 2004; Antras et al. 2009; Siegel and Larson 2009). We extend this literature by exploring a unique dataset on subsidiary-level investment decisions by MNCs around the world. MNCs are an increasingly common organizational form and yet we know little about the factors driving their 
investment decisions, in particular, the role of the external information environment in facilitating their investment. This is particularly important because MNCs face substantial crossborder frictions and the role of the information environment in resolving such frictions is potentially large. Our results suggest that the external information environment helps mitigate the agency problems that arise when firms expand their operations across borders.

\section{PRIOR RESEARCH AND HYPOTHESES}

\section{Information Frictions within MNCs}

The importance of information frictions within MNCs (and within multi-segment firms generally defined) becomes readily apparent when parents and subsidiaries are viewed within a principal-agent framework. Parent firms allocate resources across subsidiaries and therefore face the need to monitor their activities. However, increased information frictions and moral hazard within firms make resource allocation challenging for the parent (Stein 1997; Hope and Thomas 2008; Graham et al. 2011). For example, information frictions can arise within multi-segment firms due to conflicting operational styles or corporate cultures across segments (Bushman et al. 2004). Further, unlike single segment firms, in multi-segment firms the individual business segments are shielded from takeover pressures (Cusatis et al. 1993) and divisional managers are less likely to receive powerful equity incentives (Schipper and Smith 1986) leading to an increase in moral hazard.

The severity of such moral hazard and information frictions in multi-segment firms is likely to be exacerbated in MNCs as compared to domestic firms. Specifically, MNCs face crossborder frictions arising from geographic dispersion, cultural and language differences, differing legal systems, etc., which make it more difficult to monitor and/or incentivize divisional managers (Hamilton and Kashlak 1999; Mian 2006; Bell et al. 2012; Dellestrand and Kappen 
2012). In response to these information frictions, prior studies show that MNCs seek to reduce the costs of monitoring subsidiaries by reallocating decision rights (Desai et al. 2004), sharing ownership with local partners (Antras et al. 2009), and improving information technology systems (Bloom et al. 2012). However, despite these internal mechanisms, there is still evidence of substantial cross-sectional variation in the efficiency of decision-making within MNCs (Caves 2007). For example, Mian (2006) shows that the foreign branches of multinational banks are less likely to lend to small, albeit fundamentally solvent, businesses because the profitability of such loans is difficult for foreign branches to communicate to the parent banks. We build on this line of research, but with an important distinction. In contrast to prior studies that focus on internal mechanisms, we investigate whether external sources, specifically the degree of transparency in the information environment in which the subsidiary operates, help MNCs monitor their subsidiaries' decisions and mitigate information frictions within the firm.

\section{The Role of the External Information Environment}

The idea that the external information environment provides information about firm performance dates back to the literature on relative performance evaluation. Holmstrom (1979) shows that external information from competitors can be used to benchmark managerial performance and improve compensation contracts. ${ }^{3}$ Holmstrom and Tirole (1993) show that external information aggregated in stock price can be used as a monitoring mechanism to reduce agency problems and improve firm performance. We build on this literature by developing predictions about the role of the external information environment in monitoring managers' investment decisions. We focus on investment decisions because it is one of the most important managerial decisions and one of the most fundamental drivers of firm value (Hubbard 1998).

\footnotetext{
${ }^{3}$ More broadly, the literature on information transfer shows that competitors' disclosure activities affect investors' perceptions about related firms (Foster 1981).
} 
Prior studies argue that better information can improve investment because it allows shareholders to better monitor managerial actions (Bushman and Smith 2001; Chen et al. 2007). Further, recent papers show that information about one firm can affect competitors' investments. Durnev and Mangen (2009) and Kedia and Philippon (2009) present evidence that a firm's misreporting activities, proxied by accounting restatements and fraud, can lead to sub-optimal investment by competitors due to their reliance on erroneous information. Sidak (2003) presents similar arguments by arguing that WorldCom's fraudulent disclosure and financial reports had negative real effects on other telecom firms, governments, and capital markets. ${ }^{4}$

We hypothesize that the information environment in which the foreign subsidiary operates, defined as the quantity and quality of information disclosed by peer firms and information intermediaries, can help MNCs monitor a subsidiary's investment decisions. This occurs because parents can gain insights about managerial actions by observing external information. For example, they can use external information to forecast the demand in the subsidiary's line of business, the extent of competition, and the profitability and investment outlays of direct competitors, all of which can be used to benchmark the actions and performance of subsidiary managers. In other words, a rich external information environment enables parents to better evaluate whether its subsidiary's investments are in line with the subsidiary's growth opportunities. This could then mitigate subsidiary managers' incentives to shirk and/or divert resources to seek private gain, leading us to our first hypothesis:

$H_{1}$ : The sensitivity of investment to local growth opportunities is higher for subsidiaries operating in more transparent information environments.

While we focus on the potential role played by the external information environment in resolving information frictions within $\mathrm{MNCs}$ and facilitating monitoring, an alternative

\footnotetext{
${ }^{4}$ Sidak (2003) finds that WorldCom's falsified reports and disclosures led to: (i) overinvestment in network capacity, (ii) the formulation of flawed government telecommunication policies, and (iii) the sustained retrenchment of financing sources away from future telecom investment projects. Also see Li (2012), Badertscher et al. (2013) and Beatty et al. (2013).
} 
hypothesis is that MNCs monitor subsidiary managers through other mechanisms. For example, Antras et al. (2009) find that MNCs often enter foreign markets through a wholly owned subsidiary when there is higher risk of misappropriation by the foreign subsidiary. If other mechanisms, such as ownership interest, allow MNCs to completely resolve the information frictions between the parent and subsidiary in a cost effective manner, then the information environment would have little role to play in facilitating subsidiaries' investment decisions. Ultimately, it is an empirical question as to whether the external information environment facilitates monitoring within MNCs.

\section{Cross-Sectional Predictions}

In this section, we develop two predictions based on cross-sectional differences in the extent to which the external information environment facilitates subsidiaries' investment decisions. First, we hypothesize that the role of the external information environment in facilitating a subsidiary's investment decision is greater when there are greater cross-border frictions between the parent and subsidiary. The idea is that when cross-border frictions are high, such as when the parent and the subsidiary are geographically distant, the external information environment can play a greater role in disciplining subsidiary managers by providing parent firms with information about the local economic environment. This occurs because the value of external information that can be obtained from the local information environment, such as performance benchmarks and local investment opportunities, is relatively more important when the parent firm is more uncertain about the growth opportunities available to the subsidiary. In contrast, when cross-border frictions are low, the costs of exchanging information between parents and subsidiaries are similarly low, which likely results in greater information transfers from the subsidiary to the parent and vice versa (Grinblatt and Keloharju 2001; Di Giovanni 2005; Giroud 2013). Such information sharing allows the parent to better evaluate the context 
within which their subsidiary managers make their investment decisions with lesser reliance on the external information environment. ${ }^{5}$ The above discussion leads to our next hypothesis.

$H_{2}$ : The effect of the information environment on the sensitivity of investment to growth opportunities is greater when there are greater cross-border frictions between the parent and subsidiary.

Our second cross-sectional prediction is based on the allocation of investment decisionmaking rights between parents and subsidiaries. An important assumption in our main hypothesis is that the parents are involved in their subsidiaries' decision-making process. As a result, parents use the information available in their subsidiaries' operating environment to evaluate and monitor their investment decisions. However, prior research finds that some parents delegate their decision-making rights to subsidiary managers and design incentive schemes to align the subsidiary's interests with their own (Ghoshal and Nohria 1989; Ittner and Larcker 2001). In such a scenario, the external information environment is likely to play a relatively smaller role in helping parents monitor their subsidiaries, at least with respect to investment decisions. ${ }^{6}$ Based on the above argument, we hypothesize that the external information environment will be relatively more important in facilitating the subsidiary's investment decisions when the parent is more involved in the subsidiary's investment decision-making process.

$H_{3}$ : The effect of the information environment on the sensitivity of investment to growth opportunities is stronger when parents are more involved in the subsidiary's investment decision-making process.

Implicit in the development of the preceding two hypotheses is that the extent of crossborder frictions (H2) and the allocation of the investment decision rights (H3) are independent of each other. However, it is plausible that cross-border frictions affect the allocation of decision-

\footnotetext{
${ }^{5}$ Note that if alternative internal mechanisms, such as ownership interest and the allocation of decision rights, fully resolve cross-border frictions within MNCs, we would expect a null result for $\mathrm{H} 2$.

${ }^{6}$ The alternative hypothesis is that the external information environment could still be used by the parent to incentivize the manager, e.g., through relative performance evaluation contracts. To the extent that such incentive mechanisms lead to more efficient investment, we would expect a null result for our third hypothesis.
} 
making rights. ${ }^{7}$ In untabulated analyses, we find that the correlation between these constructs is small in magnitude (ranging from -0.001 to 0.184). Further, our inferences are unchanged when we control for decision-making rights in our test of cross-border frictions and vice versa. However, for the ease of exposition and to make our empirical models more tractable, we examine these hypotheses independently.

\section{SAMPLE SELECTION AND EMPIRICAL DESIGN}

\section{Data}

We use the ORBIS database published by Bureau van Dijk (BvD), which includes ownership and financial information about public and private firms worldwide. BvD compiles information on public and private firms directly from annual reports and other well-established national data providers. ${ }^{8}$ We collect financial data for parents and subsidiaries from the 2010 CDs of the BvD industrial financial database. The majority of the subsidiaries report their financials using local accounting standards and approximately two percent of our sample firms report under IFRS. In addition to financial information, ORBIS provides additional firm-level information, including management and board member characteristics, industry classification, and country of domicile. A limitation of the ORBIS database is cross-country variation in subsidiary coverage due to the differences in the reporting requirements across countries. ${ }^{9}$ As a

\footnotetext{
${ }^{7}$ For example, parent firms could retain greater control of the decision process when cross-border frictions are high, in an attempt to reduce agency costs. Alternatively, it is plausible that parent firms delegate decision-making rights to local managers when cross-border frictions are high to better exploit their knowledge of local growth opportunities in the subsidiary's country (i.e., there might be greater demand for local expertise).

${ }^{8}$ The providers include World'Vest Base (WVB) and six regional data providers: Edgar Online (USA), Huaxia International Business credit consulting company (China), Korea Information Service (Korea), Teikoku Databank (Japan), Reuters (USA), and Thompson Financial.

${ }^{9}$ For example, in most European countries, both public and private companies are required to disclose annual financial data, while in North America only public firms are required to provide such information. As most subsidiaries are privately owned, North American subsidiaries are under-represented in the ORBIS database. Even within Europe there is cross-country variation in the reporting requirements of private firms. In some countries (e.g., Russia, Switzerland, and Ukraine), private firms are not required to provide financial information. In countries like Austria, private firms are required to provide only a few basic financial items.
} 
result, subsidiaries in some countries are under-represented in our sample. We address this limitation by studying within-country variation in subsidiary investment as we describe later.

We first construct the business group structure of MNCs by linking subsidiaries to parents using the BvD ownership database as illustrated in the appendix. We define the ultimate parents as firms in which no single corporate shareholder owns more than $25 \%$ of the firms' shares, following the guidance in the ORBIS manual. Subsidiaries include firms both directly owned by the parent (Level 1) and subsidiaries indirectly owned via ownership of other subsidiaries (Levels 2, 3, and 4). We exclude subsidiaries with missing information on immediate ownership. This step reduces concerns about double-counting subsidiaries that appear multiple times at different ownership levels. We classify a business group as an MNC if it directly holds at least one subsidiary operating in a foreign country. ${ }^{10}$

We use all available data, subject to some minimal constraints. First, we exclude subsidiaries that are financial holding companies because they are less likely to invest in physical assets. We drop subsidiaries that lack the data to compute the growth opportunity measure that we describe below and subsidiaries with limited financial information in their unconsolidated financial statements. ${ }^{11}$ All parents and subsidiaries are required to have at least USD 10,000 in assets and sales to minimize outliers in computation of sales and asset growth. This leaves us

\footnotetext{
${ }^{10}$ One important limitation of the ORBIS database is that the ownership structure could be stale. That is, ORBIS only reports subsidiary information as of the database's most recent update. For example, if an MNC has no subsidiary in India before 2010, the most recent year in the database, but in 2010 it acquired an Indian firm that existed prior to 2010, we would erroneously treat the MNC as owning the Indian subsidiary for all years in our sample. Likewise, if a company had a subsidiary in India for the length of our sample but liquidated it in 2009, we would erroneously treat the MNC as not owning a subsidiary in India for all years in our sample. To assess whether this limitation affects our results, we follow Markle and Shackelford (2010) and select the last three years for which we have data as the cut-off for our sensitivity tests. The intuition is that because subsidiary ownership is likely to be sticky, there are likely to be fewer errors in the years immediately preceding 2010 than there would be earlier. In untabulated results, we find the coefficient for the interaction between PE and IE is positive and statistically significant, suggesting that our inferences are not significantly affected by this limitation.

${ }^{11}$ An exception is that when subsidiaries hold other Level 2 and 3 subsidiaries, we use the consolidated financial statements when the unconsolidated statements are not available. Due to this restriction, many subsidiaries in North America are excluded from our analysis.
} 
with a sample of 65,922 parent-subsidiary-year observations. We then initially exclude domestic subsidiaries where cross-border frictions are absent but later use these domestic subsidiaries as a benchmark sample in Section V. These restrictions yield a sample of 32,163 parent-subsidiaryyear observations from 2000 to 2009. Our final sample consists of 2,249 parents and 6,298 foreign subsidiaries spanning 63 countries. Table 1 describes our sample selection process.

Table 2, Panel A shows the distribution of parents and subsidiaries by country. The distribution is unbalanced for both parent and subsidiary firms. For example, the United States is home to many parents but not many subsidiaries. Belgium, in contrast, has far more subsidiaries than parents, and Germany shows a high concentration of both parents and subsidiaries. Panel B shows the geographic distribution of subsidiaries by parent region. In other words, the table is structured so that each row (i.e., each parent region) adds up to $100 \%$. A large proportion of parents are located in North America, with some significant representation in East Asia and Western Europe, while the majority of subsidiaries are located in Eastern and Western Europe. Among European parents, the high percentage in the diagonal of the matrix indicates that most subsidiaries are established within the parent's region. This suggests that the preference for geographically proximate investments, which is well-documented in the equity home bias literature (Portes and Rey 2005), is also observed in our MNC sample. However, there is still substantial variation in subsidiary location. For example, for parents from South American countries, $10.6 \%$ of their foreign subsidiaries are in South America, $17.0 \%$ in North America, and $50.3 \%$ in Western Europe.

\section{Research Design}

Our main prediction is that the external information environments in which subsidiaries operate enable parents to better monitor their subsidiary's actions, which affects the subsidiary's 
investment decisions. To test this prediction, we examine whether the sensitivity of a subsidiary's investment to its growth opportunities is affected by its information environment. Prior research interprets this sensitivity as a desirable feature of investment (Bekaert et al. 2007; Bushman et al. 2011; Badertscher et al. 2013). The intuition is that investment is more responsive to investment opportunities when the adjustment costs are low (Hubbard 1998). ${ }^{12}$

To test our prediction, we estimate the following regression model using ordinary least squares (OLS) with subsidiaries indexed as $i$, parents as $m$, parents' countries as $p$, subsidiaries' countries as $s$, subsidiaries' industries as $j$ and each year in the sample as $t$.

$$
\begin{aligned}
I N V_{i, t}= & \beta P E_{s, j, t} \times I E_{s, j, t}+\Sigma \beta_{s} P E_{s, j, t} \times \text { Country }_{s}+\sum \beta_{k} P E_{s, j, t} \times \text { Internal }_{k}+\sum \alpha_{m} M N C_{m}+\Sigma \alpha_{p, s} \\
& \text { Country } y_{p, s}+\Sigma \alpha_{j} \text { Industry }_{j}+\sum \alpha_{k} \text { Internal }_{k}+\text { Controls }_{1}+\varepsilon_{i, t}, \quad(1)
\end{aligned}
$$

where $I N V$ is a firm-level proxy for the subsidiary's investment, $P E$ is the price-to-earnings ratio used as a proxy for the subsidiary's growth opportunities, $I E$ is a proxy for the transparency of the external information environment, Internal $k_{k}$ is a set of internal mechanisms, Controls is a set of control variables associated with investment, $M N C_{m}$ are fixed effects for each parent firm, Country $_{p, s}$ are parent-subsidiary country-pair fixed effects, and Industry $y_{j}$ are industry fixed effects. The coefficient of interest is $\beta$, which captures the incremental sensitivity of investment to growth opportunities $(I N V-P E)$ in more transparent information environments. Our prediction is that subsidiaries in more transparent environments exhibit greater $I N V-P E$ sensitivity than subsidiaries in less transparent environments, consistent with $\mathrm{H}_{1}: \beta>0$.

The three main variables in equation (1) are investment, growth opportunities, and the information environment, discussed in the next section. Ideally, we would proxy for investment using capital expenditures and/or acquisitions. However, these data are not available for our

\footnotetext{
${ }^{12}$ Adjustment costs arise from information frictions such as adverse selection and moral hazard, among other things, leading to too little investment in growing projects and too much investment in declining projects. When adjustment costs are low, investment is more efficient because firms can more rapidly increase (decrease) investment in growing (declining) businesses/industries.
} 
sample of largely private subsidiaries. Thus, we proxy for subsidiary investment using the percentage change in total assets in a year (Badertscher et al. 2013). Following Bekaert et al. (2007), we use the price-to-earnings (PE) ratio of the country-industry-year in which the subsidiary operates as our proxy for growth opportunities. ${ }^{13,14}$ Bekaert et al. (2007) point out that an advantage of using the industry PE ratio as a proxy for growth opportunities is that this measure is relatively exogenous to an individual firm's investment choices. We obtain monthly PE ratios from Datastream and annualize them using the median ratio in the calendar year.

Equation (1) includes a series of fixed effects intended to capture unobservable characteristics that affect subsidiary investment. First, because our coefficient of interest is the sensitivity of investment to growth opportunities, we include a series of interactions that could affect this relation. Specifically, in equation (1), we allow the coefficient for $P E_{s, j, t}$ to vary by country by interacting $P E_{s, j, t}$ with indicator variables for each country where the subsidiary is located, yielding one estimated $\beta$ for each country 's.' This is important because prior research finds that country-level institutional features, such as financial development and capital market integration, lead to differences in investment efficiency (Wurgler 2000; Bekaert et al. 2007). By including interaction terms between $P E$ and country indicators, we control for the effect of country-level factors on investment efficiency. Further, measurement error in the PE ratio across countries could lead to biases in our inferences to the extent that the measurement error is correlated with differences in the information environment across countries (Erickson and Whited 2000). By allowing $I N V-P E$ sensitivities to vary by country, we effectively control for

\footnotetext{
${ }^{13}$ An alternative is to measure the PE ratio for each subsidiary. However, because most subsidiaries in our sample are not publicly traded, we are unable to measure subsidiary-specific PE ratios.

${ }^{14} \mathrm{PE}$ ratios can be interpreted as the price paid for a dollar of the firm's current earnings. Thus, when the riskiness of the earnings stream, accounting practices, the degree of market efficiency, etc., are held constant, the differences in PE ratios are likely to capture differences in available growth opportunities (Bekaert et al. 2007).
} 
cross-country differences in measurement error in PE across countries and identify our effect of interest from within-country variation in the information environment.

Second, we control for a series of mechanisms that could affect investment and/or be used to monitor a subsidiary's decisions (labeled 'Internal' and 'PE $\times$ Internal'). Specifically, we control for the parent firm's cash flow, because prior research finds that parent cash flows affect subsidiary investment through internal capital markets (Shin and Stulz 1998). ${ }^{15}$ We also control for the parent's ownership interest in the subsidiary because prior research finds that MNCs adjust their ownership to mitigate incentive problems between the parent and subsidiary (Antras et al. 2009). ${ }^{16}$ Finally, we control for the availability of local bank financing to control for additional bank monitoring that can affect the subsidiary's investment decisions. As ORBIS has very limited data on an individual subsidiary's bank loans, we use the total banking credit extended in the subsidiary's country (Domestic Banking Credit) to proxy for bank monitoring. Domestic Banking Credit is measured as the sum of all credit provided by the banking sector as a percentage of GDP. Finally, we note that although data limitations preclude us from directly controlling for all possible internal mechanisms, controlling for the interaction between $P E$ and country indicators (discussed above) allows us to indirectly control for them as long as these mechanisms are largely driven by country-level factors. ${ }^{17}$

\footnotetext{
${ }^{15}$ We use the cash flows obtained for the parent's consolidated financial statement as we do not have the financial statements on a parent-only basis.

${ }^{16}$ Prior literature finds that the parent ownership percentage does not always reflect the control rights of the parent firm over the subsidiary, especially when MNCs are structured as family-controlled business groups (Claessens et al. 2000). In untabulated analysis, we use 1) the position of each firm in the group, reflecting the number of firms that exist between the parent and subsidiary and 2) cash flow rights, measured as the sum of the minimum percentage ownership linking the parent and the subsidiary (La Porta et al. 1999) as alternative measures of control rights. Using these alternative measures of control rights yields similar inferences. Note that throughout the draft, the phrase "similar inferences" indicates that our results are statistically significant at the $10 \%$ level of better and the coefficients are of the same sign and similar magnitudes.

${ }^{17}$ For example, Antras et al. (2009) and Robinson and Stocken (2013) find that country-level factors such as investor protection and financial development influence a number of MNC characteristics such as ownership (e.g., joint venture vs. wholly owned subsidiaries), capital structure, organizational design (e.g., centralized vs. decentralized management), etc.
} 
We also control for a series of fixed effects that directly influence investment. First, we include indicator variables for each parent firm. This allows us to account for unobserved factors that affect investment decisions at the parent-firm level. For example, one could argue that certain MNCs are simply more successful in exploiting growth opportunities and that our results could reflect their preference for operating in more transparent environments. Including these indicator variables restricts the variation in subsidiary investment to within the MNC, thereby controlling for unobservable MNC-level factors that might affect investment.

Second, it is plausible that subsidiary investment is driven by the characteristics of the subsidiary's country relative to the parent's country, including differences in corporate tax rate, property rights, etc. For example, the U.S. offers much stronger property rights protection relative to India, which may cause Indian $\mathrm{MNCs}$ to conduct their $\mathrm{R} \& \mathrm{D}$ operations via subsidiaries located in the U.S. To control for such relative differences in country characteristics that might affect investment, we include indicator variables for each parent-subsidiary countrypair in our regressions. Third, we include industry fixed effects to capture differences in the industry characteristics of each subsidiary, such as production adjustment costs, that could affect investment. Finally, our set of Controls includes the subsidiary firm size (log of total assets) and performance (ROA) to control for subsidiary scale and profitability.

\section{The External Information Environment}

We use three proxies for the transparency of the external information environment (IE) based on (i) the amount of information produced by financial analysts, (ii) the amount of information produced by the business press, and (iii) the extent of earnings management by related firms. ${ }^{18} \mathrm{~A}$ notable feature is that these proxies are computed at the aggregate country-

\footnotetext{
${ }^{18}$ Our proxies for the information environment assume that increasing the quantity of information weakly increases information quality as investors and market participants can always ignore any additional information that is not
} 
industry level to capture the external information environment, making them exogenous to a subsidiary's investment decisions.

Analyst Coverage: Our first measure of the quality of the information environment is the number of analysts following the firms in each country-industry-year. Financial analysts collect, process, and disseminate information about firm performance and future outlook (Beyer et al. 2010; De Franco and Hope 2011). Prior research suggests that greater analyst coverage is related to higher reporting transparency (Lang and Lundholm 1996; Hope 2003; Lang et al. 2004), lower information uncertainty (Zhang 2006), and greater industry-wide information transfer (Piotroski and Roulstone 2004). The role of financial analysts as information intermediaries has been recognized in fields outside of accounting. For example, in the international business literature, Bell et al. (2012) suggest that financial analysts can help alleviate the cross border frictions for firms operating in a foreign country.

We compute analyst following as the number of analysts following the firm. Firms without coverage in $\mathrm{I} / \mathrm{B} / \mathrm{E} / \mathrm{S}$ are assumed to have no analyst coverage ${ }^{19}{ }^{\mathrm{We}}$ then compute the median number of analysts following the firms in each country-industry-year. We use the quartile rank of the country-industry analyst coverage every year as our first measure of $I E .^{20}$

Press Coverage: Our second proxy for the quality of the external information environment is the amount of press coverage received by firms in a country-industry-year. Prior

relevant to them. This assumption is in line with prior disclosure theories. For example, Leuz and Verrecchia (2000, 91) note that, "the theory is sufficiently broad as to allow the notion of 'increased levels of disclosure' to be interpreted as either an increase in the quantity of disclosure or an increase in the quality of disclosure (or both)."

${ }^{19}$ We note that differences in $\mathrm{I} / \mathrm{B} / \mathrm{E} / \mathrm{S}$ coverage across countries could affect the validity of this assumption. For example, in 2005, 28\% (49\%) of firms in Australia (Austria) have at least one analyst according to I/B/E/S. However, we do not know if the remaining firms missing coverage in $\mathrm{I} / \mathrm{B} / \mathrm{E} / \mathrm{S}$ represent zero analyst coverage or $\mathrm{I} / \mathrm{B} / \mathrm{E} / \mathrm{S}$ data biases. To reduce the possibility that our inferences are affected by such country-specific biases, we include country fixed effects in our regression specification so that we make inferences from within-country variations in investment.

${ }^{20} \mathrm{We}$ use quartile ranks to reduce the measurement error in the information environment proxies and to ease interpretation. However, our inferences remain unchanged when we use a continuous version of our information environment proxies. 
research finds that the pressure created by press coverage can play an important role in monitoring and disciplining firms. For example, Dyck et al. (2008) find that press coverage affects the amount of corporate resources that are diverted to the sole advantage of the controlling shareholders. Miller (2006) finds that the press plays an important monitoring role by identifying accounting irregularities and by publicizing irregularities identified by other information intermediaries. Collectively, the evidence from prior research suggests that press coverage helps improve firms' information environments by identifying and disseminating a variety of corporate governance issues.

We use a large proprietary dataset of press coverage received by more than 28,000 firms over more than 11 years and 86 different countries, compiled by RavenPack. RavenPack collects this extensive dataset from different press sources, including news wires, disclosures to regulators, credit rating agencies, etc. We compute press coverage as the median number of articles about a firm in each country-industry-year. We use the quartile rank of the countryindustry press coverage each year as our second measure of $I E .^{21}$

Earnings Transparency: Our final measure of the quality of the information environment is the degree of earnings transparency by firms in each country-industry. The idea is that if the accounting information surrounding a firm is less precise and conceals economic performance, it can adversely affect the investment decisions of related firms. For example, Durnev and Mangen (2009) show that a firm's past misreporting activities, as proxied by restatement announcements, affects competitors' past investment decisions. Following prior literature, we use the magnitude of accruals relative to the magnitude of cash flows as a proxy for earnings management (Leuz et al. 2003; Barth et al. 2008; Hope et al. 2013). We calculate this measure as the absolute value of

\footnotetext{
${ }^{21}$ Shroff et al. (2013) examine the overlap in monthly press release frequency between RavenPack and Factiva (an extensive press release database commonly used by researchers) for a random sample of 50 firms in the U.S. and find that the correlation in press-release frequency is $94.7 \%$ suggesting that the database is fairly comprehensive.
} 
accruals scaled by the cash flow from operations for the median firm in each country-industryyear. We multiply the measure by -1 and refer to it as earnings transparency for exposition. We use the quartile rank of country-industry each year as the final measure of $I E$.

\section{EMPIRICAL RESULTS}

\section{Descriptive Statistics}

Table 3 presents the descriptive characteristics of the parents and foreign subsidiaries in our sample. Panel A shows the results for all firms. Untabulated results indicate that MNCs in our sample hold three foreign subsidiaries on average, which translates into 13.2 subsidiaryyears. The average investment rate among subsidiaries is $18 \%$ of assets and the average $P E$ is 19.6. The average asset size of subsidiaries in our sample is USD 24.9 million and the average subsidiary $R O A$ is $3.3 \%$. Untabulated descriptives show that the parents are much larger in size with average assets of USD 19.4 billion but they have a comparable mean ROA (3\%). Panel A also shows that the average cash flow from operations (CFO) generated by parent firms is $8.6 \%$ of assets. The average ownership in its subsidiaries is $76.4 \%$, which is partly driven by our sampling requirement that parents have at least $25 \%$ ownership interest in the entity for it to be included as a subsidiary.

Table 3, Panel B presents the mean and standard deviation of $P E$ and our proxies for $I E$ by each country in our sample. The descriptive statistics are reported at the industry-year level (2,540 industry-years) in each country because we measure $P E$ and $I E$ at the industry level. The table shows that there is considerable variation in $P E$ and in our $I E$ measures within each country. For example, the average within-country standard deviation in analyst coverage (media coverage) for our sample of countries is 3.81 (1.56). This variation is important because our research design exploits only within-country variation in $I E$ to explain $I N V-P E$ sensitivities. The 
table also shows that there is considerable variation in the number of industry-year observations. In untabulated analyses, we find that our inferences are unchanged if we restrict our sample to include only countries with at least 15 industry-year observations.

\section{Regression Results: The Role of the Information Environment}

Table 4 presents the results from estimating equation (1). In column 1, we present the baseline regression specification of $I N V$ on $P E$ and control variables. To ease the interpretation of the coefficient for $P E$, this model excludes the interactions between the country fixed effects and $P E$. The table shows that the coefficient for $P E$ is positive and statistically significant at the $\mathrm{p}<0.01$ level (coef. $=0.06$, t-stat $=2.85$ ). This result confirms the findings in Bekaert et al. (2007) for our sample and suggests that firms' investment decisions are associated with industrylevel $P E$ ratios. In subsequent models, we control for the interaction between the country indicators and $P E$; therefore, the coefficient for $P E$ is not directly interpretable as it captures the baseline relation between $P E$ and $I N V$ in the country whose fixed effect is excluded from the regression. Therefore, we do not tabulate the coefficient for $P E$ in our remaining analyses.

Columns 2-4 in Table 4 show that the coefficient for the interaction between growth opportunities and information environment $(P E \times I E)$ is positive and statistically significant for all three measures of the information environment. Specifically, the coefficient for the interaction ranges from 0.19 to 0.23 and is statistically significant at the $p<0.05$ level or better. In economic terms, a one standard deviation increase in growth opportunities (which equals 17 in Table 3, Panel A) translates to approximately a $4 \%$ increase in investment for firms in the top analyst coverage quartile and a $1 \%$ increase for those in the bottom quartile. That is, there is approximately a 3\% difference in investment between firms in the highest and lowest analyst 
coverage quartile for a one standard deviation change in $P E .^{22}$ Given that the average investment in our sample equals $18 \%$, this represents a relative difference of approximately $17 \%$.

In the final column in Table 4, we aggregate our three IE proxies by taking the average of their ranks. This procedure helps reduce measurement errors in the individual proxies. Consistent with the results in the previous columns, we find that the coefficient for $P E \times I E$ is positive and statistically significant at the $\mathrm{p}<0.01$ level. Overall, the results presented in Table 4 indicate that the sensitivity of investment to growth opportunities is higher for subsidiaries located in countryindustries with more transparent information environments, consistent with $\mathrm{H} 1$.

Table 4 also shows that the coefficients for ROA, Parent CFO, and Parent Ownership are consistently positive and statistically significant, indicating that better performing subsidiaries and subsidiaries whose parents have greater cash flows and ownership tend to invest more. Further, the coefficient for $P E \times$ Domestic Banking Credit is also positive and significant, indicating that the availability of bank financing increases the $I N V-P E$ sensitivity. Together, the coefficients for $R O A$ and $P E \times$ Domestic Banking Credit suggest that financing constraints might be affecting subsidiaries' investments and that the availability of bank financing helps to partially mitigate this constraint.

\section{Cross-Sectional Results}

Next, we examine our cross-sectional hypotheses, which predict differences in the importance of the role of the external information environment by (i) the level of cross-border frictions (H2) and (ii) the extent to which the parent is involved in the subsidiary's investment decision-making process (H3).

\footnotetext{
${ }^{22}$ Specifically, we obtain our estimate of economic significance by taking the product of the PE*IE coefficient, the standard deviation of $\mathrm{PE}$, and the difference between the fourth and first quartiles of IE, where the quartile ranks are scaled by four. In numeric terms, this equals $0.23 \times 17 \times(1-0.25)$.
} 
To test H2, we partition the sample into two groups based on the level of cross-border frictions between the parent and subsidiary and we estimate equation (1) separately for the two sub-samples. Following prior literature, we consider three proxies that capture cross-border frictions between the parent and subsidiary. The first proxy is based on the commonality of languages spoken in the parent's and subsidiary's countries. Sharing a common language reduces information asymmetry by reducing the transaction cost of exchanging information across borders. For example, Grinblatt and Keloharju (2001) find that investors prefer to hold equities in firms that share the investor's native tongue. Similarly, Di Giovanni (2005) examines crossborder acquisitions and finds that sharing a common language helps reduce the cost of doing business across borders. If the parent and subsidiary are incorporated in countries that share a common official language, we consider cross-border frictions to be low. ${ }^{23}$

Our second proxy for cross-border frictions is based on the geographic distance between the parent and subsidiary. Prior studies interpret geographic distance as a measure of information acquisition cost and/or information asymmetry (Anderson and Van Wincoop 2004). Consistent with this interpretation, prior research finds that geographic distance accounts for much of the variation in the cross-border flows of both real goods and financial assets (Portes and Rey 2005; Mian 2006). We measure Geographic Distance as the distance between the parent's and subsidiary's countries of incorporation. If the geographic distance between the parent country's capital and the subsidiary country's capital is greater than the median distance in our sample, we consider the cross-border frictions to be high.

\footnotetext{
${ }^{23}$ An official language is defined as the primary and secondary language used in each country, according to the World Fact Book (CIA 2011). For example, English is a common official language shared by the U.S. and India, which facilitates communication between managers in these countries. However, China and the U.S. do not have a common official language, making bilateral communication more difficult.
} 
Our final proxy for cross-border frictions is based on the difference in operating risks in the parent's and the subsidiary's country. Prior studies argue that operating risks such as infrastructure risks, customer risks, political risks, etc. are higher in emerging markets than in developed economies (Kwok and Reeb 2000). ${ }^{24}$ Thus, when MNCs from developed countries invest in emerging economies their operating risk increases although the reverse does not increase operating risk. In the context of our study, an increase in operating risks implies higher cross-border frictions. Thus, we predict that the role of the information environment will be stronger when parents from developed countries invest in emerging economies. ${ }^{25} \mathrm{We}$ classify countries into developed and emerging markets following Kwok and Reeb (2000) and the International Monetary Fund's 1999 Capital Market Report (see Table 2, Panel A).

To better understand our cross-sectional tests, consider the following example. Both Italy and the U.K. are resident to parent firms that have subsidiaries in Canada. However, unlike the U.K., Italy does not share a common official language with Canada. Therefore, cross-border frictions between Italian parents and their Canadian subsidiaries are higher than the frictions between the U.K. parents and their Canadian subsidiaries. Our prediction is that, holding the subsidiary's location constant, the incremental $I N V-P E$ sensitivity due to higher $I E$ in Canada is greater for subsidiaries owned by Italian parents than it is for the subsidiaries owned by U.K. parents. Therefore, this test compares the investment behavior of subsidiaries located in the same country and exploits variation in the parents' locations, thereby mitigating concerns arising from cross-country differences in the investing/institutional environment, such as cross-country differences in financial development, corruption, growth opportunities, etc.

\footnotetext{
${ }^{24}$ For example, infrastructure risk includes the increased risk of transportation delays due to fewer highways, railways, less developed air routes and greater susceptibility to route closures, as well as a greater risk of telephone and power outages and delays in mail delivery (Kwok and Reeb 2000).

${ }^{25}$ Following Kwok and Reeb (2000), we assume that the parent-subsidiary pairs operating within emerging (or developed) economies face similar operating risks and thus do not lead to increases in operating risk.
} 
Table 5 presents the results from estimating equation (1) on high and low cross-border friction partitions. Although we tabulate results using an aggregate of our three IE proxies, our inferences are unchanged when we use individual IE proxies. We find that when cross-border frictions are high, the coefficient for $P E \times I E$ is positive and significant. For instance, the coefficient for $P E \times I E$ is positive and statistically significant when the parent and subsidiary are located in countries that do not share a common language (coef. $=0.55$, t-stat $=3.34$ ), but statistically insignificant when parents and subsidiaries share a common language (coef. $=-0.76$, tstat=-1.27). The results using Geographic Distance and Operating Risk as proxies for crossborder frictions offer similar inferences. We also test and find that the coefficients $P E \times I E$ are statistically different from each other for high versus low cross-border friction subsidiaries. ${ }^{26}$ Overall, the results in Table 5 are consistent with $\mathrm{H} 2$ and suggest that the information environment has a greater effect on the sensitivity of investment to growth opportunities when there are greater cross-border frictions between the parent and the subsidiary.

To test H3, we partition the sample based on the allocation of decision-making rights between the parent and subsidiary. Here again, we estimate equation (1) separately for the two sub-samples of subsidiaries classified based on the allocation of decision-making rights. We use three proxies to capture variation in the extent to which the parent is involved in the subsidiary's investment decision-making process. Our first proxy is the subsidiary's relative size based on total assets. Prior research finds that larger subsidiaries are more likely to have decision-making rights (Robinson and Stocken 2013). The size and scope of large subsidiaries makes it more difficult for managers at the parent firm to obtain and process all the information needed to

\footnotetext{
${ }^{26}$ We test for the difference in coefficients using a bootstrap test. Specifically, we randomly assign the distance classification to each observation and estimate model (1) for the pseudo high and low distance groups, respectively. We then compute a pseudo difference in coefficients for the high and low distance pairs. Repeating this procedure 1,000 times yields a null distribution of the difference in coefficients, which we use to test the significance of the difference in coefficients we report in Tables 5 and 6.
} 
facilitate decision-making. Hence, decision-making in larger subsidiaries is more likely to be at the subsidiary level with less involvement from the parent. To measure a subsidiary's relative size within each MNC, we sort subsidiaries into two groups based on their total assets. We classify subsidiaries with above median total assets relative to the assets of other subsidiaries owned by the same MNC as having a more autonomous decision-making process.

Our second proxy exploits the nationality of the subsidiary's management team and board members to identify the location of decision-making rights. These data are available in the ORBIS dataset. Parents are more likely to send expatriates to help manage the subsidiary when they wish to be involved in the subsidiary's decision-making process. However, when local knowledge and relationships are important for decision-making, the subsidiary's management team is more likely to be comprised of local managers who are native to the subsidiary's country (Ahlstrom and Bruton 2010). Empirically, we classify subsidiaries whose management team has more (fewer) expatriates than the sample median as having higher (lower) parent firm involvement in the subsidiary's decision-making processes. ${ }^{27}$

Our final proxy for decision rights examines whether a subsidiary operates in the same industry as the parent firm. The international management literature shows that parents of MNCs are more likely to be involved in the subsidiary's decision making process when they possess greater knowledge of the project (Björkman et al. 2004). Following prior research, we assume that parent firm managers' are likely to possess greater knowledge of the subsidiary's operations when the subsidiary operates in the same industry as the parent (Goodman et al. 2013). We use

\footnotetext{
${ }^{27}$ Expatriates are defined as members of the management team whose nationality is different from the country where the subsidiary is domiciled. We obtain the nationality of the individual managers from ORBIS. The management team is defined as all senior managers, C-suite executives in operations and R\&D, and the board of directors. $28 \%$ of the managers in our sample have missing data on nationality in ORBIS. While we drop these observations in our main analysis, untabulated results show that the findings are robust to assuming the managers with missing nationality information to be local managers.
} 
the one-digit ICB code to classify the parent-subsidiary pairs into those operating in the same versus different industries.

Table 6 presents these results. Consistent with $\mathrm{H} 3$, the coefficient for $P E \times I E$ is positive and significant for the sub-sample of subsidiaries with low decision-making rights, but insignificant and smaller in magnitude for the sub-sample of more autonomous subsidiaries. These results suggest that the role of the information environment in facilitating subsidiary investment is greater when parents are more involved in their subsidiary's decision-making.

\section{Time Series Variation in the Information Environment}

Our main tests explore cross-sectional variation in the information environment. We now use IFRS adoption as a proxy for a time-series change in financial reporting standards that led to a significant change in the information environment. We then examine whether the investment decisions of subsidiaries located in IFRS-adopting countries improves following IFRS adoption. Prior research finds that voluntary and mandatory IFRS adoption is associated with higher earnings "quality" (Barth et al. 2008; Landsman et al. 2012) and a significant reduction in information asymmetry (e.g., Daske et al. 2008, 2013; Wahid and Yu 2013). Thus, IFRS adoption serves as another proxy for the richness of the external information environment, which complements the three measures we use in our main tests.

We examine the change in $I N V-P E$ sensitivities for subsidiaries located in IFRS-adopting countries using a difference-in-differences design. In contrast to prior studies that focus on the firm adopting IFRS, we use IFRS adoption as an event that triggers a change in the external information environment. Thus, we consider both mandatory as well as voluntary adopters of IFRS when constructing our proxy for IFRS adoption. For our first proxy, we obtain from Daske et al. (2008) the list of countries that mandatorily adopted IFRS in 2005 (with the exception of 
Singapore which adopted IFRS in 2003) and include a dummy variable 'Post 2005' for sample years post 2005 in equation (1). In this model, we limit our sample to countries that have a low rate $(<25 \%)$ of early voluntary adopters because, to the extent a significant number of firms voluntarily adopt IFRS before 2005 , the mandatory adoption date is less likely to serve as a significant shift in the external information environment. ${ }^{28}$ For our second proxy, we include all IFRS-adopting countries but re-code the post-2005 variable to capture the percentage of firms adopting IFRS in a country over the sample period. For example, $26.4 \%$ to $36.1 \%$ of the firms in Germany voluntarily adopted IFRS between 2001 and 2004, before it was mandated in 2005 . Therefore, we create a variable labeled ' $\% I F R S$ ' that takes on values ranging from 0.264 to 0.361 in the periods 2001 to 2004 and is set equal to 1 following mandatory adoption. We then focus on the difference in difference coefficient for countries with and without IFRS adoption ('PE $\times$ Post $2005 \times$ IFRS Country' and 'PE $\times \%$ IFRS $\times$ IFRS Country'). Note that, because our model includes an interaction between $P E$ and each country, the interaction between $P E$ and $I F R S$ Country is absorbed by the country-PE fixed effects.

Table 7, column 1 presents the results after excluding subsidiaries located in countries with more than $25 \%$ of the firms voluntarily adopting IFRS and column 2 uses the proportion of IFRS-adopting firms in a country to proxy for the change in the external information environment. Column 1 shows that the coefficient for PE $\times$ Post $2005 \times$ IFRS Country is positive and statistically significant ( $t$-stat $=1.86)$. The magnitude of the coefficient $(0.25)$ is similar to what we report in column 4 suggesting that the change in the $I N V-P E$ sensitivity pre- vs. postIFRS is similar to the cross-sectional effect of our earlier proxies for the information environment. Column 2 presents the results with after considering a gradual change to IFRS. The

\footnotetext{
${ }^{28}$ Specifically, we exclude Austria, the Czech Republic, Germany, Hungary, Italy, Luxembourg, and Switzerland because more than $25 \%$ of the firms in these countries voluntarily adopted IFRS well before the mandatory adoption date. We obtain the rate of voluntary IFRS adoption from Daske et al. (2008).
} 
coefficient for $P E \times \% I F R S \times I F R S$ Country is also positive and statistically significant (tstat $=2.78$ ) with a similar magnitude to that found in column 1 . These results strengthen our inference that a richer external information environment facilitates the investment decisions of subsidiaries.

\section{ADDITIONAL ANALYSES AND ROBUSTNESS TESTS}

\section{Analyses of Benchmark Firms}

Our results thus far show that the local information environment is an important determinant of foreign subsidiaries' investment efficiency. Further, our results are stronger when cross-border frictions are high and when parents are more actively involved in a subsidiary's decision-making process. To further validate our inferences, we benchmark our findings for foreign subsidiaries to those obtained using two "placebo" samples where cross-border frictions are non-existent and the parent-subsidiary relationship is less applicable. First, we compare our findings for foreign subsidiaries to those for domestic subsidiaries of MNCs. Since domestic subsidiaries (as we define them) are located in the same country as the parent, cross-border frictions are absent. Second, we compare our findings for foreign subsidiaries to that for a matched sample of foreign standalone firms that operate in the same country-industry-year and are of similar size (measured using total assets) as the foreign subsidiary. The notion of parentsubsidiary relationships do not apply to standalone firms and by definition, these firms do not suffer from cross-border frictions. Therefore, we predict that the local information environment has a smaller effect on the investment decisions of domestic subsidiaries and foreign standalone firms operating in the same countries as our foreign subsidiaries.

We estimate equation (1) for the sample of domestic subsidiaries and a modified version of equation (1) for the sample of foreign standalone firms and compare these results with those 
for foreign subsidiaries. ${ }^{29}$ Table 8 reports the results. To facilitate the comparison, we reproduce the results from Table 4 that estimate equation (1) for the sample of foreign subsidiaries. The results show that the interaction between growth opportunities and the information environment is not significant among domestic subsidiaries (column 2) and foreign standalone firms (column 3). These results contrast with the positive and statistically significant coefficient for $P E \times I E$ for the sample of foreign subsidiaries. Further, the differences between the coefficients are statistically significant at the $\mathrm{p}<0.01$ level. Overall, these results are consistent with our hypotheses that the external information environment is an important driver of investment efficiency, especially when cross-border frictions are high and when the parent firms demand information because of their involvement in the subsidiary's investment decisions.

\section{Untabulated Robustness Tests}

We conduct two additional robustness tests tabulated and described in detail in an online appendix..$^{30}$ First, we examine whether our results are robust to controlling for additional factors that drive the MNC's initial decision to invest in a country. MNCs' investment decisions can be separated into two distinct stages: (i) the decision to first enter a country and (ii) the decision to make ongoing investments conditional on entry. While our interest lies in the second stage, a potential concern with our tests is that our findings could simply reflect the role of transparency in the initial investment decision. More broadly, foreign investments made by MNCs are a subset of FDI flows into a country and thus it is conceivable that our results are capturing the determinants of FDI documented in prior research. While our main tests include a series of fixed

\footnotetext{
${ }^{29}$ We modify equation (1) for standalone firms by removing control variables related to the parent-subsidiary relationship. Specifically, we are unable to control for Parent CFO, Parent Ownership and these variables interacted with $P E$. In addition, MNC indicator variables and parent-subsidiary pair indicator variables also do not apply. Finally, our sample size for standalone firms is smaller (31,957 observations) because we are unable to find a matching foreign subsidiary for some observations. In untabulated analyses, we find that our inferences from Table 4 are identical with this different regression specification and smaller sub-sample of matched foreign subsidiaries.

${ }^{30}$ The online appendix can be downloaded here: http://www.mit.edu/ rverdi/.
} 
effects that capture many of the determinants of FDI, we also re-run our tests controlling for additional time-varying drivers of FDI, such as the level of corruption (Alesina and Weder 2002), GDP growth, the currency exchange rate (Froot and Stein 1991), and the interest rate differentials between the parent's and subsidiary's countries (Gross and Trevino 1996). We find that our results are robust to addition of these control variables (see Table OA1 in the online appendix).

Next, we examine whether our robust to using an alternative measure of investment efficiency - Total Factor Productivity (TFP). TFP is the portion of output not explained by the inputs used in a firm's production and, therefore, measures how efficiently and intensely the inputs (capital and labor) are utilized in the production process (Schoar 2002). We find that TFP is positively associated with all our transparency proxies (see Table OA2 in the online appendix). These results suggest that our prior results on the relation between the information environment and the sensitivity of investment to growth opportunities manifest as higher productivity for subsidiaries located in more transparent information environments.

\section{CONCLUSION}

We test whether the external information environment in which subsidiaries operate helps MNCs monitor their subsidiaries' investment decisions. Prior research emphasizes that crossborder frictions lead to an increase in information frictions between parents and their subsidiaries, which creates a demand for information that parents can use to monitor and evaluate their subsidiaries. Based on this argument, we hypothesize that external information, such as that generated by other firms in the industry or by information intermediaries, can be used to enhance managerial investment decisions inside the firm.

We find robust evidence that the sensitivity of subsidiary investment to growth opportunities is higher in country-industries with better information environments. Further, the 
role of the information environment on the sensitivity of investment to growth opportunity is greater when i) there are greater cross-border frictions between the parent and the subsidiary and ii) when the parent is more involved in its subsidiary's investment decision-making processes.

This paper contributes to the literature on the real effects of accounting information. While recent research examines whether and why the quality of information disclosed by a firm affects the disclosing firm's investment decisions, we examine the effects of firms' disclosures and information intermediary coverage on the investment decisions of peer firms. Our paper also contributes to prior research on MNCs' investment decisions and more broadly, the literature on foreign direct investments. MNCs are unique because they are subject to frictions arising from operating in many different countries. MNCs deal with these cross-border frictions by altering contract design, sharing ownership with local partners, etc. Our findings suggest that the external information environment is another mechanism that helps mitigate cross-border frictions.

Our study exploits a novel dataset in the ownership structure of MNCs to provide preliminary evidence on the role of information in facilitating investment decisions in MNCs. While we have described limitations of this dataset, it provides an important opportunity to study MNC behavior. Our paper leaves open a number of subsequent research opportunities. For example, given our findings, one can examine the other types of internal governance mechanisms, such as compensation schemes, that MNCs use to mitigate cross-border friction, and how such internal mechanisms interact with the local environment in the country where the subsidiary operates. Finally, our study focuses only on the investment behavior of MNCs. Future research can extend this line of inquiry by examining other outcomes such as organizational design, incentive systems, and financing decisions. 


\section{REFERENCES}

Ahlstrom, D., and G. Bruton. 2010. International Management: Strategy and Culture in an Emerging World. Ohio: South-Western Cengage Learning.

Alesina, A., and B. Weder. 2002. Do corrupt governments receive less foreign aid? American Economic Review 92 (4): 1126-1137.

Anderson, J., and E. Van Wincoop. 2004. Trade costs. Journal of Economic Literature 42 (3): 691751.

Anthony, R., 1965. Planning and Control Systems: A Framework for Analysis. Harvard University Press, Boston, MA.

Antras, P., M.A. Desai, and C.F. Foley. 2009. Multinational firms, FDI flows, and imperfect capital markets. The Quarterly Journal of Economics 124 (3): 1171-1219.

Armstrong, C., W. Guay, and J. Weber. 2010. The role of information and financial reporting in corporate governance and debt contracting. Journal of Accounting and Economics 50 (2-3): 179-234.

Badertscher, B., N. Shroff, and H. White. 2013. Externalities of public firm presence: evidence from private firms' investment decisions. Journal of Financial Economics 109: 682-706.

Barth, M., W. R. Landsman, and M. H. Lang. 2008. International accounting standards and accounting quality. Journal of Accounting Research 46: 467-498.

Beatty, A., S. Liao, and J. Yu. 2013. The spillover effect of fraudulent financial reporting on peer firms' investment efficiency. Journal of Accounting and Economics 55, 183-205.

Bell, R.G., I. Filatotchev, and A.A. Rasheed. 2012. The liability of foreignness in capital markets: Sources and remedies. Journal of International Business Studies 43: 107-122.

Bekaert, G., C. Harvey, C. Lundblad, and S. Siegel. 2007. Global growth opportunities and market integration. Journal of Finance 62: 1081-1137.

Beyer, A., D. Cohen, T. Lys, and B. Walther. 2010. The financial reporting environment: Review of the recent literature. Journal of Accounting and Economics 50: 296-343.

Biddle, G.C., G. Hillary, and R.S. Verdi. 2009. How does financial reporting quality relate to investment efficiency? Journal of Accounting and Economics 48 (2-3): 112-131.

Björkman, I., W. Barner-Rasmussen, and L. Li. 2004, Managing knowledge transfer in MNCs: The impact of headquarters control mechanisms. Journal of International Business Studies 35 (5): 443-455. 
Bloom, N., R. Sadun, and J. Van Reenen. 2012. Americans do I.T. better. US multinationals and the productivity miracle. American Economic Review 102 (1): 167-201.

Bruns Jr., W. J., and J.H., Waterhouse. 1975. Budgetary control and organizational structure. Journal of Accounting Research: 177-203.

Bushman, R.M., Q. Chen, E., Engel, and A.J. Smith. 2004. Financial accounting information, organizational complexity and corporate governance systems, Journal of Accounting and Economics 37: 167-201.

Bushman, R.M., J.D. Piotroski, and A.J. Smith. 2011. Capital allocation and timely accounting recognition of economic losses. Journal of Business, Finance and Accounting 38 (1-2): 1-33.

Bushman, R.M., and A.J. Smith. 2001. Financial accounting information and corporate governance. Journal of Accounting and Economics 1-3: 237-333.

Caves, Richard E. 2007. Multinational Enterprise and Economic Analysis. $3^{\text {rd }}$ ed. Cambridge: Cambridge University Press.

Chen, Q., I. Goldstein, and W. Jiang. 2007. Price informativeness and investment sensitivity to stock price. Review of Financial Studies 20 (3): 619-650.

Chen, F., O. Hope, Q. Li, and X. Wang. 2011. Financial reporting quality and investment efficiency of private firms in emerging markets. The Accounting Review 86 (4): 1255-1288.

Chenhall, R. 2003. Management control system design within its organizational context: findings from contingency-based research and direction for the future. Accounting Organizations and Society 28:127-168.

Claessens, S., S. Djankov, and L. H.P. Lang. 2000. The separation of ownership and control in East Asian corporations, Journal of Financial Economics 58: 81-112.

Cusatis, P., J.A. Miles, and R. J. Wooldridge. 1993. Restructuring through spin-offs. Journal of Financial Economics 33:293-311.

Daske, H., L. Hail, C. Leuz, and R. Verdi. 2008. Mandatory IFRS reporting around the world: Early evidence on the economic consequences. Journal of Accounting Research 46: 1085-1142.

Daske, H., L. Hail, C. Leuz, and R. Verdi. 2013. Adopting a Label: Heterogeneity in the Economic Consequences around IAS/IFRS Adoptions. Journal of Accounting Research forthcoming.

Datar, S.M., M. Rajan, and C.T., Horngren 2013. Managerial Accounting: Decision Making and Motivating Performance. NJ: Prentice Hall.

De Franco, G., and O-K. Hope. 2011. Do analysts' notes provide new information? Journal of Accounting Auditing and Finance 26 (2): 229-254. 
Dellestrand, H. and P. Kappen. 2012. The effects of spatial and contextual factors on headquarters resource allocation to MNE subsidiaries. Journal of International Business Studies 43(3):219243.

Desai, M., F. Foley, and J.R. Hines. 2004. The costs of shared ownership: Evidence from international joint ventures. Journal of Financial Economics 73 (2): 323-374.

Desai, M., F. Foley, and J.R Hines. 2009. Domestic effects of the foreign activities of US multinationals, American Economic Journal: Economic Policy 1 (1): 181-203.

Di Giovanni, J. 2005. What drives capital flows? The case of cross-border M\&A activity and financial deepening. Journal of International Economics 65: 127-49.

Durnev, A., and C. Mangen. 2009. Corporate investments: Learning from restatements. Journal of Accounting Research 47: 679-720.

Dyck, A., N. Volchkova, and L. Zingales. 2008. The corporate governance role of the media: Evidence from Russia. The Journal of Finance 63 (3): 1093-1135.

Erickson, T., and T. Whited. 2000. Measurement error and the relationship between investment and Q. Journal of Political Economy 108: 1027-1057.

Foster, G. 1981. Intra-industry information transfers associates with earnings releases. Journal of Accounting and Economics 3: 201-232.

Froot, K., and J. Stein. 1991. Exchange rates and foreign investment: An imperfect capital markets approach. Quarterly Journal of Economics 106 (4): 1191-1217.

Ghoshal, S. and N. Nohria. 1989. Internal differentiation within multinational corporations. Strategic Management Journal 10: 323-337.

Giroud, X. 2013. Proximity and Investment: Evidence from Plant-Level Data. Quarterly Journal of Economics 128: 861-915.

Goodman, T, M. Neamtiu, N. Shroff, and H. White. 2013. Management Forecast Quality and Capital Investment Decisions. The Accounting Review, forthcoming.

Graham, J., C. Harvey, and M. Puri. 2011. Capital allocation and delegation of decision-making authority within firms. NBER Working Paper No. w17370.

Grinblatt, M., and M. Keloharju. 2001. Distance, language, and culture bias: The role of investor sophistication. Journal of Finance 56: 1053-1073.

Gross R., and L.J Trevino. 1996. Foreign direct investment in the United States: An analysis by country by origin. Journal of International Business Studies 27 (1): 139-155. 
Hamilton, R.D. III, and R. J. Kashlak. 1999. National influences on multinational corporate control system select. Management International Review 39 (2): 167-189.

Holmstrom, B. 1979. Moral hazard and observability. Bell Journal of Economics 10: 74-91.

Holmstrom, B., and T. Tirole. 1993. Market liquidity and performance monitoring, Journal of Political Economy 10: 678-709.

Hope, O.-K. 2003. Disclosure practices, enforcement of accounting standards, and analysts' forecast accuracy: An international study. Journal of Accounting Research 41 (2): 235-272.

Hope, O.-K, and W. Thomas. 2008. Managerial empire building and firm disclosure. Journal of Accounting Research 46: 591-626.

Hope, O.-K, W. Thomas, and D. Vyas. 2013. Financial Reporting Quality of U.S. Private and Public Firms. The Accounting Review, forthcoming.

Hubbard, R.G. 1998. Capital-market imperfections and investment. Journal of Economic Literature 35: 193-225.

Ittner, C. D., and D. F. Larcker. 2001. Assessing empirical research in managerial accounting: A value-based management perspective. Journal of Accounting and Economics 32: 349-410.

Kedia, S., and T. Philippon. 2009. The economics of fraudulent accounting. Review of Financial Studies 22: 2169-99.

Kwok, C.Y. and D. Reeb. 2000. Internationalization and firm risk: An upstream-downstream hypothesis. Journal of International Business Studies 31 (4): 611-629.

Landsman, W. R., E. L. Maydew, and J. R. Thornock. 2012. The information content of annual earnings announcements and mandatory adoption of IFRS. Journal of Accounting and Economics 53: 34-54.

Lang, M., K. Lins, and D. Miller. 2004. Concentrated control, analyst following, and valuation: Do analysts matter most when investors are protected least? Journal of Accounting Research 42: 589-623.

Lang, M., and R. Lundholm. 1996. Corporate disclosure policy and analyst behavior. The Accounting Review 71: 467-492.

La Porta, R., F. Lopez-de-Silanes, and A. Shleifer. 1999. Corporate ownership around the world. Journal of Finance 54: 471-517.

Leuz, C., D., Nanda, and P. Wysocki. 2003. Earnings management and investor protection: An international comparison. Journal of Financial Economics 69: 505-527. 
Leuz, C., and R.E. Verrecchia. 2000. The economic consequences of increased disclosure. Journal of Accounting Research 38: 91-124.

Li, V. 2012. Do False Financial Statements Lead Peer Firms to Make Distorted Decisions? An Analysis of Peer Firms' Real Operating Decisions during Periods of Misreporting. Unpublished working paper.

Markle, K. S., and D. A. Shackleford. 2010. Do Multinationals or Domestic Firms Face Higher Effective Tax Rates? Working paper, University of North Carolina.

Mian, A. 2006. Distance constraints: The limits of foreign lending in poor economies. Journal of Finance 61 (3): 1465-505.

Miller, G. 2006. The press as a watchdog for accounting fraud. Journal of Accounting Research 44: 1001-1033.

Piotroski, J.D., and D. T. Roulstone. 2004. The influence of analysts, institutional investors, and insiders on the incorporation of market, industry, and firm-specific information into stock prices. The Accounting Review 79 (4): 1119-1151.

Portes, R., and H. Rey. 2005. The determinants of cross-border equity flows. Journal of International Economics 65: 269-296.

Robinson, L., and P. Stocken. 2013. Location of Decision-Rights within Multinational Firms. Journal of Accounting Research, forthcoming.

Roth, K., and S.W. O'Donnell. 1996. Foreign subsidiary compensation strategy: An agency theory perspective. Academy of Management Journal 39: 678-703.

Schipper, K., and A. Smith. 1986. A comparison of equity carve-outs and seasoned equity offerings. Journal of Financial Economics: 153-186.

Schoar, A. 2002. Effects of corporate diversification on productivity. Journal of Finance: 2379-2403.

Shin, H. H., and R. Stulz. 1998. Are internal capital markets efficient? Quarterly Journal of Economics 113: 531-552.

Shroff, N., A. Sun, H. White, and W. Zhang. 2013. Voluntary Disclosure and Information Asymmetry: Evidence from the 2005 Securities Offering Reform. Journal of Accounting Research, forthcoming.

Sidak, J. G. 2003. The failure of good intentions: The WorldCom fraud and the collapse of American telecommunications after deregulation. Yale Journal on Regulation 20: 207-67.

Siegel, J., and B. Zepp Larson. 2009. Labor market institutions and global strategic adaptation: Evidence from Lincoln Electric. Management Science 55 (9): 1527-1546. 
Smith, P. 2001. How do foreign patent rights affect U.S. exports, affiliate sales and licenses? Journal of International Economics 55: 411-439.

Stein, J. 1997. Internal capital markets and the competition for corporate resources. Journal of Finance 52: 111-133.

Wahid, A. and G. Yu. 2013. Accounting Standards and International Portfolio Holdings. Unpublished working paper.

Wurgler, J. 2000. Financial markets and the allocation of capital. Journal of Financial Economics 58: $187-214$.

Zaheer, S. 1995. Overcoming the liabilities of foreignness. Academy of Management Journal 38: 341363.

Zhang, X. 2006. Information uncertainty and stock returns. Journal of Finance 61: 105-136. 
APPENDIX

\section{Linking Parent and Subsidiaries in ORBIS Database}

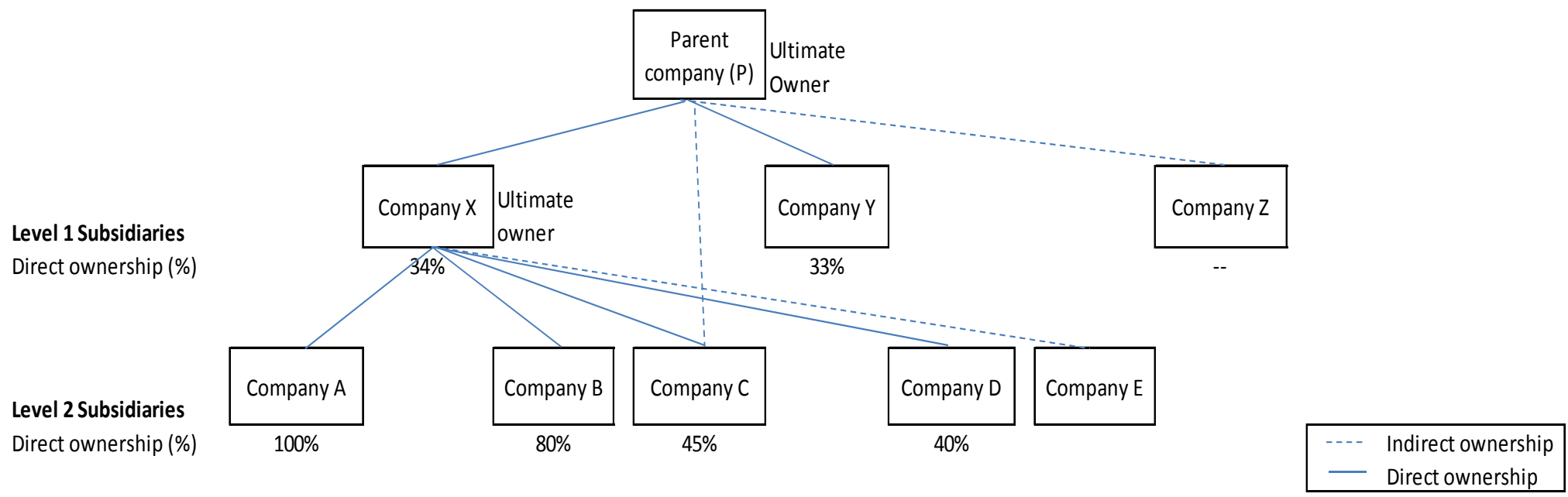

Parent-subsidiary dataset structure

\begin{tabular}{llll}
\hline Parent & Subsidiary & Levels & Ownership (\%) \\
$\mathrm{P}$ & $\mathrm{X}$ & 1 & $34 \%$ \\
$\mathrm{P}$ & $\mathrm{Y}$ & 1 & $33 \%$ \\
$\mathrm{P}$ & $\mathrm{A}$ & 2 & $34 \%(=34 \% * 100 \%)$ \\
$\mathrm{P}$ & $\mathrm{B}$ & 2 & $27 \%(=34 \% * 80 \%)$ \\
$\mathrm{P}$ & $\mathrm{C}$ & 2 & $15 \%(=34 \% * 45 \%)$ \\
$\mathrm{P}$ & $\mathrm{D}$ & 2 & $14 \%(=34 \% * 40 \%)$ \\
\hline
\end{tabular}

Step 1: Identify parent companies from the ultimate owner ${ }^{1}$ dataset in ORBIS.

Step 2: Link subsidiaries (Level 1) to the parent companies. We define subsidiaries as firms that are held with more than $25 \%$ direct ownership. ${ }^{2} \mathrm{We}$ exclude firms that are indirectly held. ${ }^{3}$

Step 3: Link subsidiaries (Level 2) to the Level 1 subsidiary companies. Repeat process for Level 3 and 4 subsidiaries.

\footnotetext{
${ }^{1}$ Ultimate owner: A firm where the shareholder with the highest direct ownership is an independent entity. To be an independent entity, the shareholder must be an individual or an entity with no shareholder owning more than $25 \%$ ownership.

${ }^{2}$ Direct ownership: ownership representing voting shares that are directly held.

${ }^{3}$ Indirect ownership: ownership representing voting shares that are held through an unknown entity.
} 
TABLE 1

\section{Sample Selection}

This table presents our sample selection procedure. We require firm-years to have data on net income for both the parent and the subsidiary. In addition, we require both parents and subsidiaries to have at least USD 10,000 in assets and sales.

Panel A: Sample selection

\begin{tabular}{lcc}
\hline & $\begin{array}{c}\text { Observations } \\
\text { Dropped }\end{array}$ & $\begin{array}{c}\text { \# Parent-Subsidiary-Year } \\
\text { Observations }\end{array}$ \\
\hline \hline Parent - sub years with financials and industry codes & & 120,105 \\
Excluding subsidiaries that are financial holding companies & 31,245 & 88,860 \\
Excluding subsidiaries located in country-industry-years with no & 22,938 & 65,922 \\
PEs & 33,759 & 32,163 \\
Excluding domestic subsidiaries & & 32,163 \\
Final MNC parent-subsidiary year & & \\
\hline \hline
\end{tabular}

Panel B: Firm-year observations

\begin{tabular}{lcc}
\hline & \multicolumn{1}{c}{ Main } & Control \\
& Sample & Sample \\
\cline { 2 - 3 } & $\begin{array}{c}\text { Foreign } \\
\text { Subsidiaries }\end{array}$ & $\begin{array}{c}\text { Domestic } \\
\text { Subsidiaries }\end{array}$ \\
\hline \# of parent-subsidiary-years & 32,163 & 33,759 \\
\# of unique subsidiaries & 6,298 & 6,019 \\
\# of unique parents & 2,249 & 1,091 \\
\hline \hline
\end{tabular}


TABLE 2

Sample Composition by Country, Geographic Region, and Industry

Panel A: Sample distribution by country

\begin{tabular}{|c|c|c|c|c|c|c|c|c|c|}
\hline \multirow{2}{*}{ Country } & \multicolumn{2}{|c|}{ Parent } & \multicolumn{2}{|c|}{ Subsidiary } & \multirow{2}{*}{ Country } & \multicolumn{2}{|c|}{ Parent } & \multicolumn{2}{|c|}{ Subsidiary } \\
\hline & \# of obs & $\%$ of obs & \# of obs & $\%$ of obs & & \# of obs & $\%$ of obs & \# of obs & $\%$ of obs \\
\hline ARGENTINA (E) & 2 & $0.0 \%$ & 410 & $1.3 \%$ & KUWAIT & 49 & $0.2 \%$ & 0 & $0.0 \%$ \\
\hline AUSTRALIA & 330 & $1.0 \%$ & 225 & $0.7 \%$ & LIBERIA & 2 & $0.0 \%$ & 0 & $0.0 \%$ \\
\hline AUSTRIA & 233 & $0.7 \%$ & 30 & $0.1 \%$ & LUXEMBOURG & 100 & $0.3 \%$ & 0 & $0.0 \%$ \\
\hline BELGIUM & 304 & $0.9 \%$ & 2,345 & $7.3 \%$ & MALAYSIA (E) & 62 & $0.2 \%$ & 322 & $1.0 \%$ \\
\hline BERMUDA & 149 & $0.5 \%$ & 0 & $0.0 \%$ & MARSHALL ISLANDS & 7 & $0.0 \%$ & 0 & $0.0 \%$ \\
\hline BRAZIL (E) & 29 & $0.1 \%$ & 55 & $0.2 \%$ & $\operatorname{MEXICO}(\mathrm{E})$ & 28 & $0.1 \%$ & 9 & $0.0 \%$ \\
\hline CANADA & 403 & $1.3 \%$ & 131 & $0.4 \%$ & NETHERLANDS ANTILLES & 21 & $0.1 \%$ & 0 & $0.0 \%$ \\
\hline CAYMAN ISLANDS & 44 & $0.1 \%$ & 0 & $0.0 \%$ & NEW ZEALAND & 42 & $0.1 \%$ & 62 & $0.2 \%$ \\
\hline CHILE (E) & 21 & $0.1 \%$ & 0 & $0.0 \%$ & NORWAY & 470 & $1.5 \%$ & 613 & $1.9 \%$ \\
\hline CHINA (E) & 5 & $0.0 \%$ & 992 & $3.1 \%$ & PAKISTAN & 5 & $0.0 \%$ & 14 & $0.0 \%$ \\
\hline COLOMBIA (E) & 0 & $0.0 \%$ & 6 & $0.0 \%$ & PERU (E) & 3 & $0.0 \%$ & 40 & $0.1 \%$ \\
\hline CROATIA & 16 & $0.0 \%$ & 0 & $0.0 \%$ & PHILIPPINES (E) & 0 & $0.0 \%$ & 2 & $0.0 \%$ \\
\hline CYPRUS & 36 & $0.1 \%$ & 0 & $0.0 \%$ & POLAND (E) & 10 & $0.0 \%$ & 810 & $2.5 \%$ \\
\hline CZECH REPUBLIC (E) & 5 & $0.0 \%$ & 225 & $0.7 \%$ & PORTUGAL & 37 & $0.1 \%$ & 470 & $1.5 \%$ \\
\hline DENMARK & 529 & $1.6 \%$ & 0 & $0.0 \%$ & ROMANIA & 24 & $0.1 \%$ & 81 & $0.3 \%$ \\
\hline EGYPT (E) & 2 & $0.0 \%$ & 0 & $0.0 \%$ & RUSSIA & 15 & $0.0 \%$ & 0 & $0.0 \%$ \\
\hline FINLAND & 717 & $2.2 \%$ & 1,048 & $3.3 \%$ & SINGAPORE (E) & 157 & $0.5 \%$ & 308 & $1.0 \%$ \\
\hline FRANCE & 2,293 & $7.1 \%$ & 5,164 & $16.1 \%$ & SLOVAKIA & 2 & $0.0 \%$ & 0 & $0.0 \%$ \\
\hline GERMANY & 2,068 & $6.4 \%$ & 1,348 & $4.2 \%$ & SLOVENIA & 25 & $0.1 \%$ & 0 & $0.0 \%$ \\
\hline GIBRALTAR & 3 & $0.0 \%$ & 0 & $0.0 \%$ & SOUTH AFRICA (E) & 99 & $0.3 \%$ & 22 & $0.1 \%$ \\
\hline GREECE (E) & 50 & $0.2 \%$ & 411 & $1.3 \%$ & SPAIN & 624 & $1.9 \%$ & 1,896 & $5.9 \%$ \\
\hline HONG KONG (E) & 33 & $0.1 \%$ & 9 & $0.0 \%$ & SRI LANKA & 6 & $0.0 \%$ & 0 & $0.0 \%$ \\
\hline HUNGARY (E) & 0 & $0.0 \%$ & 5 & $0.0 \%$ & SWEDEN & 1,302 & $4.0 \%$ & 1,635 & $5.1 \%$ \\
\hline ICELAND & 12 & $0.0 \%$ & 0 & $0.0 \%$ & SWITZERLAND & 0 & $0.0 \%$ & 1 & $0.0 \%$ \\
\hline INDIA (E) & 262 & $0.8 \%$ & 457 & $1.4 \%$ & TAIWAN (E) & 243 & $0.8 \%$ & 0 & $0.0 \%$ \\
\hline INDONESIA (E) & 0 & $0.0 \%$ & 74 & $0.2 \%$ & THAILAND (E) & 2 & $0.0 \%$ & 926 & $2.9 \%$ \\
\hline IRELAND & 172 & $0.5 \%$ & 161 & $0.5 \%$ & TUNISIA & 5 & $0.0 \%$ & 0 & $0.0 \%$ \\
\hline ISRAEL & 216 & $0.7 \%$ & 9 & $0.0 \%$ & TURKEY (E) & 3 & $0.0 \%$ & 29 & $0.1 \%$ \\
\hline ITALY & 230 & $0.7 \%$ & 2,525 & $7.9 \%$ & UNITED KINGDOM & 1,710 & $5.3 \%$ & 6,824 & $21.2 \%$ \\
\hline JAMAICA & 1 & $0.0 \%$ & 0 & $0.0 \%$ & UNITED STATES & 12,108 & $37.6 \%$ & 708 & $2.2 \%$ \\
\hline JAPAN & 6,481 & $20.2 \%$ & 485 & $1.5 \%$ & VIRGIN ISLANDS & 15 & $0.0 \%$ & 0 & $0.0 \%$ \\
\hline KOREA(SOUTH) (E) & 341 & $1.1 \%$ & 1,276 & $4.0 \%$ & TOTAL & 32,163 & $100 \%$ & 32,163 & $100 \%$ \\
\hline
\end{tabular}




\section{TABLE 2 (Continued)}

Panel B: Distribution of Parents and Subsidiaries by Geographic Region

\begin{tabular}{|c|c|c|c|c|c|c|c|c|c|c|}
\hline Parent $\backslash$ Subsidiary & Africa & $\begin{array}{c}\text { South } \\
\text { East } \\
\text { Asia }\end{array}$ & $\begin{array}{c}\text { Middle } \\
\text { East }\end{array}$ & $\begin{array}{l}\text { East } \\
\text { Asia }\end{array}$ & Oceania & $\begin{array}{c}\text { South } \\
\text { America }\end{array}$ & $\begin{array}{c}\text { North } \\
\text { America }\end{array}$ & $\begin{array}{l}\text { Eastern } \\
\text { Europe }\end{array}$ & $\begin{array}{l}\text { Western } \\
\text { Europe }\end{array}$ & Total (\# obs) \\
\hline \multirow{3}{*}{$\begin{array}{l}\text { Africa } \\
\text { South East Asia } \\
\text { Middle East }\end{array}$} & $0.0 \%$ & $2.8 \%$ & $0.0 \%$ & $0.0 \%$ & $3.7 \%$ & $3.7 \%$ & $4.7 \%$ & $0.0 \%$ & $85.0 \%$ & 107 \\
\hline & $0.0 \%$ & $16.2 \%$ & $0.0 \%$ & $9.7 \%$ & $2.4 \%$ & $0.0 \%$ & $11.7 \%$ & $1.0 \%$ & $58.9 \%$ & 494 \\
\hline & $0.0 \%$ & $1.8 \%$ & $0.0 \%$ & $0.0 \%$ & $0.7 \%$ & $0.0 \%$ & $15.2 \%$ & $3.2 \%$ & $79.1 \%$ & 282 \\
\hline East Asia & $0.0 \%$ & $12.5 \%$ & $0.0 \%$ & $15.0 \%$ & $1.3 \%$ & $0.7 \%$ & $4.4 \%$ & $4.6 \%$ & $61.4 \%$ & 7,103 \\
\hline Oceania & $0.0 \%$ & $10.8 \%$ & $0.0 \%$ & $5.5 \%$ & $4.5 \%$ & $0.3 \%$ & $9.0 \%$ & $11.9 \%$ & $58.0 \%$ & 379 \\
\hline South America & $0.0 \%$ & $3.2 \%$ & $0.0 \%$ & $5.4 \%$ & $4.8 \%$ & $10.6 \%$ & $17.0 \%$ & $8.7 \%$ & $50.3 \%$ & 312 \\
\hline North America & $0.1 \%$ & $4.7 \%$ & $0.1 \%$ & $7.9 \%$ & $0.8 \%$ & $2.2 \%$ & $1.2 \%$ & $13.0 \%$ & $69.9 \%$ & 12,511 \\
\hline Eastern Europe & $0.0 \%$ & $2.3 \%$ & $0.0 \%$ & $3.4 \%$ & $0.2 \%$ & $0.5 \%$ & $0.7 \%$ & $40.4 \%$ & $52.5 \%$ & 3,289 \\
\hline Western Europe & $0.1 \%$ & $5.4 \%$ & $0.0 \%$ & $6.6 \%$ & $0.5 \%$ & $1.8 \%$ & $2.0 \%$ & $19.3 \%$ & $64.3 \%$ & 7,686 \\
\hline Total & 22 & 2,103 & 9 & 2,762 & 287 & 520 & 839 & 4,857 & 20,764 & 32,163 \\
\hline
\end{tabular}

Panel A presents the distribution of both parent-year observations and subsidiary-year observations by country. (E) Denotes countries classified as emerging markets (following Kwok and Reeb 2000). Panel B presents the distribution of both parent-year observations (vertical axis) and subsidiary-year observations (horizontal axis) by geographic region. 
TABLE 3

Descriptive Statistics of Multinational Firms at the Subsidiary Level

Panel A (B) in this table presents the firm-year-level (industry-year-level) descriptive statistics for the multinational firms in our sample (by country). Asset growth is the growth in assets for each subsidiary. $P E$ is the price-to-earnings ratio for each subsidiary's country-industry-year. Analyst coverage is the median number of analysts following firms in the country-industry-year. Press Coverage is the median number of press articles about firms in the country-industry-year, and Earnings Transparency is -1 times the absolute value of the ratio of accruals scaled by the cash flow from operations for the median firm in each country-industry-year. ROA is the return on assets, that is, net income by total assets, at the subsidiary level. Ln(Assets) is the natural log of assets at the subsidiary level. Parent $C F O$ is the cash flows from operations scaled by total assets for each parent (based on the parent's consolidated financial statements). Parent Ownership is the percentage of the subsidiary's stock that is owned by the parent. For subsidiaries that are held indirectly through other firms, we use the product of all observed percentage ownership connecting the subsidiary along each chain. Domestic Banking Credit includes all credit provided domestically by the banking sector as a percentage of the Gross Domestic Product (GDP).

Panel A: Full sample

\begin{tabular}{lcccccr}
\hline \multicolumn{1}{c}{ Variable } & Mean & Stdev. & P25 & P50 & P75 & N \\
\hline \hline Number of Subsidiary-years per parent & 13.15 & 18.73 & 4.00 & 7.00 & 15.00 & 2,249 \\
Asset Growth (\%) & 17.92 & 53.98 & -7.64 & 9.18 & 28.18 & 32,163 \\
PE & 19.63 & 17.00 & 11.35 & 15.65 & 21.25 & 32,163 \\
Analyst Coverage & 1.30 & 0.47 & 1.06 & 1.23 & 1.45 & 32,163 \\
Press Coverage & 0.51 & 0.29 & 0.25 & 0.50 & 0.75 & 32,163 \\
Earnings Transparency & -0.61 & 0.28 & -0.75 & -0.50 & -0.25 & 32,163 \\
ROA (\%) & 3.32 & 23.92 & -0.58 & 4.17 & 11.42 & 32,163 \\
Ln(Assets) & 9.63 & 2.12 & 8.17 & 9.63 & 11.03 & 32,163 \\
Parent CFO (\% of assets) & 8.62 & 9.70 & 4.63 & 8.57 & 13.04 & 32,163 \\
Parent Ownership (\%) & 76.40 & 26.12 & 50.00 & 98.00 & 100.00 & 32,163 \\
Domestic Banking Credit (\% of GDP) & 130.30 & 47.24 & 33.74 & 80.78 & 105.71 & 32,163 \\
\hline \hline
\end{tabular}


TABLE 3 (Continued)

Panel B: Descriptives of PE and IE by country-industries

\begin{tabular}{|c|c|c|c|c|c|c|c|c|c|}
\hline \multirow[b]{2}{*}{ COUNTRY } & \multicolumn{2}{|c|}{$\underline{P E}$} & \multicolumn{2}{|c|}{ Analyst Coverage } & \multicolumn{2}{|c|}{ Press Coverage } & \multicolumn{3}{|c|}{ Earnings Transparency } \\
\hline & Mean & SD & Mean & SD & Mean & SD & Mean & SD & $\mathbf{N}$ \\
\hline ARGENTINA & 12.05 & 12.27 & 0.43 & 1.28 & 1.53 & 0.97 & -1.46 & 0.87 & 83 \\
\hline AUSTRALIA & 19.97 & 13.87 & 0.14 & 0.35 & 2.34 & 1.15 & -1.02 & 0.36 & 67 \\
\hline AUSTRIA & 22.79 & 24.38 & 3.37 & 6.27 & 3.05 & 2.03 & -0.99 & 0.75 & 19 \\
\hline BELGIUM & 17.97 & 16.36 & 3.12 & 4.18 & 2.07 & 1.39 & -0.99 & 0.42 & 117 \\
\hline BRAZIL & 25.86 & 29.93 & 1.33 & 2.40 & 1.99 & 1.35 & -1.06 & 0.33 & 38 \\
\hline CANADA & 29.26 & 21.15 & 0.68 & 0.75 & 2.00 & 0.80 & -0.93 & 0.41 & 60 \\
\hline CHINA & 38.91 & 21.73 & 0.00 & 0.00 & 1.92 & 0.77 & -1.21 & 0.62 & 84 \\
\hline COLOMBIA & 49.77 & 53.45 & 0.00 & 0.00 & 2.00 & 1.26 & -0.73 & 0.13 & 6 \\
\hline CZECH REPUBLIC & 37.88 & 44.55 & 0.74 & 1.83 & 1.35 & 0.74 & -1.43 & 0.79 & 39 \\
\hline FINLAND & 18.70 & 14.50 & 5.03 & 4.32 & 2.76 & 1.95 & -0.72 & 0.23 & 88 \\
\hline FRANCE & 17.24 & 12.04 & 0.98 & 1.83 & 2.74 & 1.67 & -0.95 & 0.36 & 134 \\
\hline GERMANY & 20.18 & 17.17 & 1.03 & 1.91 & 2.17 & 1.20 & -1.14 & 0.42 & 101 \\
\hline GREECE & 23.19 & 23.40 & 2.13 & 4.99 & 2.30 & 1.49 & -1.17 & 0.34 & 79 \\
\hline HONG KONG & 22.48 & 5.61 & 0.00 & 0.00 & 1.56 & 0.53 & -1.40 & 0.12 & 9 \\
\hline HUNGARY & 6.86 & 2.10 & 6.60 & 7.09 & 3.10 & 2.25 & -1.51 & 1.00 & 5 \\
\hline INDIA & 23.01 & 18.75 & 0.88 & 1.79 & 1.73 & 0.87 & -0.98 & 0.43 & 92 \\
\hline INDONESIA & 13.01 & 9.01 & 0.31 & 0.85 & 1.60 & 0.90 & -1.64 & 0.62 & 36 \\
\hline IRELAND & 12.89 & 6.70 & 2.11 & 2.23 & 1.89 & 1.01 & -1.20 & 0.87 & 46 \\
\hline ISRAEL & 10.28 & 7.88 & 0.00 & 0.00 & 1.71 & 0.76 & -1.00 & 0.22 & 7 \\
\hline ITALY & 23.40 & 21.20 & 3.27 & 4.53 & 1.92 & 1.18 & -1.13 & 0.41 & 119 \\
\hline JAPAN & 38.34 & 21.16 & 0.21 & 0.47 & 2.49 & 2.27 & -0.94 & 0.15 & 92 \\
\hline KOREA(SOUTH) & 17.75 & 17.21 & 0.10 & 0.47 & 2.00 & 1.62 & -1.15 & 0.52 & 111 \\
\hline MALAYSIA & 16.03 & 20.66 & 0.12 & 0.46 & 1.70 & 1.02 & -1.59 & 0.52 & 82 \\
\hline MEXICO & 13.93 & 1.94 & 1.17 & 2.24 & 1.11 & 0.33 & -1.70 & 0.37 & 9 \\
\hline NEW ZEALAND & 20.66 & 12.94 & 1.94 & 1.53 & 2.15 & 1.10 & -0.99 & 0.56 & 27 \\
\hline NORWAY & 29.85 & 32.89 & 4.66 & 6.98 & 1.98 & 1.37 & -1.12 & 0.62 & 59 \\
\hline PAKISTAN & 9.75 & 10.84 & 0.04 & 0.13 & 1.00 & 0.00 & -0.88 & 0.63 & 14 \\
\hline PERU & 32.07 & 27.54 & 0.28 & 0.74 & 1.46 & 0.64 & -0.93 & 0.43 & 25 \\
\hline PHILIPPINES & 11.10 & 0.21 & 0.00 & 0.00 & 2.25 & 0.35 & -1.10 & 0.23 & 2 \\
\hline POLAND & 22.69 & 20.64 & 1.33 & 2.33 & 1.64 & 1.60 & -1.46 & 0.90 & 89 \\
\hline PORTUGAL & 19.56 & 18.46 & 3.86 & 5.57 & 1.68 & 1.09 & -1.24 & 0.91 & 74 \\
\hline RUSSIA & 22.54 & 23.90 & 2.48 & 3.00 & 1.61 & 0.75 & -0.88 & 0.52 & 32 \\
\hline SINGAPORE & 20.46 & 23.74 & 1.24 & 3.68 & 1.51 & 0.63 & -1.32 & 0.54 & 72 \\
\hline SOUTH AFRICA & 14.64 & 7.61 & 0.75 & 0.95 & 1.48 & 0.82 & -0.82 & 0.44 & 22 \\
\hline SPAIN & 24.11 & 21.75 & 7.62 & 7.24 & 2.01 & 1.29 & -0.87 & 0.42 & 128 \\
\hline SWEDEN & 20.74 & 20.18 & 2.02 & 3.94 & 2.53 & 1.54 & -0.99 & 0.46 & 104 \\
\hline SWITZERLAND & 20.30 & . & 9.50 & . & 5.50 & . & -0.47 & $\cdot$ & 1 \\
\hline THAILAND & 17.76 & 17.55 & 0.41 & 0.94 & 2.30 & 1.66 & -1.14 & 0.59 & 87 \\
\hline TURKEY & 19.46 & 16.65 & 0.48 & 1.50 & 1.27 & 0.57 & -1.18 & 0.36 & 22 \\
\hline $\begin{array}{l}\text { UNITED } \\
\text { KINGDOM }\end{array}$ & 17.96 & 12.34 & 1.02 & 1.52 & 2.23 & 0.83 & -1.00 & 0.49 & 144 \\
\hline UNITED STATES & 23.49 & 11.04 & 0.72 & 1.02 & 5.07 & 2.35 & -1.09 & 0.38 & 115 \\
\hline Total & 21.84 & 20.37 & 1.79 & 3.81 & 2.18 & 1.56 & -1.11 & 0.56 & 2,540 \\
\hline
\end{tabular}


TABLE 4

\section{Investment Regressions Conditional on Information Environment}

This table presents the results from subsidiary-level regressions of asset growth on industry growth opportunities, the information environments in each country-industry-year, an interaction term between growth opportunities and the information environment and control variables. $P E$ is the price-to-earnings ratio of the country-industry-year of the subsidiary. $I E$ is the yearly quartile rank of our proxies for the information environment. We proxy for the information environment using the median number of analysts following firms in the country-industry-year (Analyst Coverage), the median number of press articles about firms in the country-industry-year (Press Coverage), and -1 times the absolute value of the ratio of accruals scaled by the cash flow from operations for the median firm in each countryindustry-year (Earnings Transparency). ROA is net income scaled by total assets. Log Assets is the natural $\log$ of the subsidiaries' total assets. Parent CFO is the cash flows from operations obtained by the parent firm that owns the subsidiary. Parent Ownership is the percentage of the subsidiary's stock that is owned by the parent. Domestic banking credit includes all credit provided domestically by the banking sector as a percentage of GDP. All regressions include the fixed effects of each parent firm, parent country-subsidiary country-pair, and the subsidiary's ICB industry. The regressions also include interaction terms between each subsidiary-country indicator and $P E$. TStatistics are reported in parentheses below the regression coefficients and we cluster standard errors at the countryindustry level. $* * * * *$, and $*$ denote statistical significance at the two-tailed $1 \%, 5 \%$, and $10 \%$ levels.

\section{Dependent Variable: Asset Growth}

\begin{tabular}{|c|c|c|c|c|c|c|}
\hline \multirow[b]{2}{*}{ Variables } & \multirow[b]{2}{*}{$\begin{array}{l}\text { Pr. } \\
\text { Sign }\end{array}$} & & \multicolumn{4}{|c|}{ Information Environment (IE) Measures } \\
\hline & & & $\begin{array}{l}\text { Analyst } \\
\text { Coverage }\end{array}$ & $\begin{array}{c}\text { Press } \\
\text { Coverage }\end{array}$ & $\begin{array}{c}\text { Earnings } \\
\text { Transparency }\end{array}$ & Aggregate \\
\hline PE & + & $\begin{array}{c}0.06^{* * *} \\
(2.85)\end{array}$ & & & & \\
\hline $\mathrm{PE} \times \mathrm{IE}$ & + & & $\begin{array}{c}0.23^{* * *} \\
(3.11)\end{array}$ & $\begin{array}{l}0.19 * * \\
(2.11)\end{array}$ & $\begin{array}{l}0.23 * * \\
(1.97)\end{array}$ & $\begin{array}{c}0.52^{* * *} \\
(3.25)\end{array}$ \\
\hline IE & & & $\begin{array}{c}-0.14 * * * \\
(-4.90)\end{array}$ & $\begin{array}{c}-0.05 \\
(-1.64)\end{array}$ & $\begin{array}{l}-0.05 \\
(-1.56)\end{array}$ & $\begin{array}{c}-0.18 * * * \\
(-3.52)\end{array}$ \\
\hline ROA & & $\begin{array}{c}0.31 * * * \\
(7.28)\end{array}$ & $\begin{array}{c}0.35 * * * \\
(11.33)\end{array}$ & $\begin{array}{c}0.35^{* * *} \\
(11.31)\end{array}$ & $\begin{array}{c}0.35^{* * *} \\
(11.33)\end{array}$ & $\begin{array}{c}0.31 * * * \\
(7.21)\end{array}$ \\
\hline Log Assets & & $\begin{array}{c}-0.07 * * * \\
(-22.84)\end{array}$ & $\begin{array}{c}-0.07 * * * \\
(-24.58)\end{array}$ & $\begin{array}{c}-0.07 * * * \\
(-24.58)\end{array}$ & $\begin{array}{c}-0.07 * * * \\
(-24.56)\end{array}$ & $\begin{array}{c}-0.07 * * * \\
(-22.40)\end{array}$ \\
\hline Parent CFO & & $\begin{array}{c}0.33^{* * *} \\
(4.14)\end{array}$ & $\begin{array}{c}0.14 * * \\
(2.41)\end{array}$ & $\begin{array}{c}0.13 * * \\
(2.37)\end{array}$ & $\begin{array}{c}0.13 * * \\
(2.39)\end{array}$ & $\begin{array}{c}0.27 * * * \\
(2.72)\end{array}$ \\
\hline Parent Ownership & & $\begin{array}{c}0.07 * * * \\
(2.95)\end{array}$ & $\begin{array}{l}0.06 * * \\
(2.03)\end{array}$ & $\begin{array}{l}0.06^{* *} \\
(2.08)\end{array}$ & $\begin{array}{l}0.06 * * \\
(2.17)\end{array}$ & $\begin{array}{l}0.06 * * \\
(2.06)\end{array}$ \\
\hline Domestic Banking Credit & & $\begin{array}{c}-0.25^{* * *} \\
(-10.07)\end{array}$ & $\begin{array}{c}-0.34 * * * \\
(-10.92)\end{array}$ & $\begin{array}{c}-0.36^{* * *} \\
(-11.12)\end{array}$ & $\begin{array}{c}-0.36^{* * *} \\
(-11.97)\end{array}$ & $\begin{array}{c}-0.35^{* * *} \\
(-11.12)\end{array}$ \\
\hline $\mathrm{PE} \times$ Parent $\mathrm{CFO}$ & & & $\begin{array}{c}0.25 \\
(1.10)\end{array}$ & $\begin{array}{c}0.27 \\
(1.16)\end{array}$ & $\begin{array}{c}0.28 \\
(1.24)\end{array}$ & $\begin{array}{c}0.25 \\
(1.11)\end{array}$ \\
\hline PE $\times$ Parent Ownership & & & $\begin{array}{c}0.06 \\
(0.81)\end{array}$ & $\begin{array}{c}0.06 \\
(0.79)\end{array}$ & $\begin{array}{c}0.05 \\
(0.66)\end{array}$ & $\begin{array}{c}0.06 \\
(0.80)\end{array}$ \\
\hline $\mathrm{PE} \times$ Domestic Banking Credit & & & $\begin{array}{c}0.68 * * * \\
(6.03)\end{array}$ & $\begin{array}{c}0.68^{* * *} \\
(5.93)\end{array}$ & $\begin{array}{c}0.72 * * * \\
(6.74)\end{array}$ & $\begin{array}{c}0.71^{* * *} \\
(6.75)\end{array}$ \\
\hline PE $\times$ Country Indicators & & No & Yes & Yes & Yes & Yes \\
\hline $\mathrm{PE} \times$ Firm-level Internal Mechanisms & & No & Yes & Yes & Yes & Yes \\
\hline MNC Indicators & & Yes & Yes & Yes & Yes & Yes \\
\hline Country Pairs Indicators & & Yes & Yes & Yes & Yes & Yes \\
\hline Industry Indicators & & Yes & Yes & Yes & Yes & Yes \\
\hline SE Clustering (Country-Industry) & & Yes & Yes & Yes & Yes & Yes \\
\hline \# Firm-Years & & 32,163 & 32,163 & 32,163 & 32,163 & 32,163 \\
\hline Adj. R-Square & & $13.2 \%$ & $13.2 \%$ & $13.1 \%$ & $13.1 \%$ & $13.2 \%$ \\
\hline
\end{tabular}




\section{TABLE 5}

\section{Investment Regressions by Cross-border Frictions between Parents and Subsidiaries}

This table presents the results from subsidiary-level regressions of asset growth on industry growth opportunities, the information environments in each country-industry-year, an interaction term between growth opportunities and the information environment and control variables. The regressions are partitioned into two groups based on the cross-border frictions between the parent and the subsidiary. $P E$ is the price-to-earnings ratio of the country-industry-year of the subsidiary. $I E$ is the yearly quartile rank of our proxies for the information environment. Common language is an indicator variable that equals one if the parent and subsidiary are incorporated in countries that share a common official language. Official language is defined as the primary and secondary languages used in each country, according to the World Fact Book (CIA, 2011). Geographic Distance is an indicator variable that equals one if the geographic distance between the parent's and subsidiary's countries is greater than the median distance for our sample firms. Operating Risk is an indicator variable that equals one if the parent is incorporated in a developed country and the subsidiary in an emerging market country. Developed countries are defined following Kwok and Reeb (2000). All other variables are as defined above Table 4. All regressions include the fixed effects of each parent firm, parent-country subsidiary-country pair, and the subsidiary's ICB industry. The regressions also include interaction terms between each subsidiary-country indicator and $P E$. T-Statistics are reported in parentheses below the regression coefficients and we cluster standard errors at the country-industry level. ***,**, and * denote statistical significance at the two tailed $1 \%$, $5 \%$, and $10 \%$ levels.

\begin{tabular}{|c|c|c|c|c|c|c|}
\hline \multicolumn{7}{|c|}{ Dependent Variable: Asset Growth } \\
\hline \multirow[b]{2}{*}{ Distance Measures: } & \multicolumn{2}{|c|}{ Common Language } & \multicolumn{2}{|c|}{ Geographic Distance } & \multicolumn{2}{|c|}{ Operating Risk } \\
\hline & $\begin{array}{l}\text { Low } \\
\text { Friction }\end{array}$ & $\begin{array}{l}\text { High } \\
\text { Friction }\end{array}$ & $\begin{array}{l}\text { Low } \\
\text { Friction }\end{array}$ & $\begin{array}{c}\text { High } \\
\text { Friction }\end{array}$ & $\begin{array}{l}\text { Low } \\
\text { Friction }\end{array}$ & $\begin{array}{l}\text { High } \\
\text { Friction }\end{array}$ \\
\hline $\mathrm{PE} \times \mathrm{IE}$ & $\begin{array}{l}-0.76 \\
(-1.27)\end{array}$ & $\begin{array}{c}0.55^{* * *} \\
(3.34)\end{array}$ & $\begin{array}{c}0.33 \\
(1.50)\end{array}$ & $\begin{array}{c}0.68^{* * *} \\
(3.25)\end{array}$ & $\begin{array}{l}0.44^{* *} \\
(2.52)\end{array}$ & $\begin{array}{l}0.78^{*} \\
(1.73)\end{array}$ \\
\hline IE & $\begin{array}{l}-0.07 \\
(-0.32)\end{array}$ & $\begin{array}{c}-0.18 * * * \\
(-3.60)\end{array}$ & $\begin{array}{l}-0.12 * * \\
(-2.04)\end{array}$ & $\begin{array}{c}-0.23 * * * \\
(-3.75)\end{array}$ & $\begin{array}{c}-0.17 * * * \\
(-3.08)\end{array}$ & $\begin{array}{c}-0.10 \\
(-1.05)\end{array}$ \\
\hline ROA & $\begin{array}{c}0.12^{* *} \\
(2.26)\end{array}$ & $\begin{array}{c}0.35^{* * *} \\
(8.38)\end{array}$ & $\begin{array}{c}0.25^{* * *} \\
(3.82)\end{array}$ & $\begin{array}{c}0.34 * * * \\
(6.84)\end{array}$ & $\begin{array}{c}0.28 * * * \\
(6.84)\end{array}$ & $\begin{array}{c}0.70^{* * *} \\
(5.43)\end{array}$ \\
\hline Log Assets & $\begin{array}{c}-0.14 * * * \\
(-8.68)\end{array}$ & $\begin{array}{c}-0.07 * * * \\
(-22.33)\end{array}$ & $\begin{array}{c}-0.08 * * * \\
(-10.20)\end{array}$ & $\begin{array}{c}-0.07 * * * \\
(-17.68)\end{array}$ & $\begin{array}{c}-0.08 * * * \\
(-19.95)\end{array}$ & $\begin{array}{c}-0.09 * * * \\
(-6.52)\end{array}$ \\
\hline Parent CFO & $\begin{array}{l}(0.01) \\
(-0.03)\end{array}$ & $\begin{array}{c}0.35^{* * *} \\
(3.06)\end{array}$ & $\begin{array}{c}0.34 * * * \\
(2.94)\end{array}$ & $\begin{array}{c}0.20 \\
(1.63)\end{array}$ & $\begin{array}{c}0.23 * * \\
(2.20)\end{array}$ & $\begin{array}{c}0.63^{* * * *} \\
(3.02)\end{array}$ \\
\hline Parent Ownership & $\begin{array}{l}-0.02 \\
(-0.14)\end{array}$ & $\begin{array}{l}0.06^{* *} \\
(2.07)\end{array}$ & $\begin{array}{c}0.04 \\
(0.85)\end{array}$ & $\begin{array}{l}0.08^{* *} \\
(2.12)\end{array}$ & $\begin{array}{l}0.08 * * \\
(2.39)\end{array}$ & $\begin{array}{c}0.04 \\
(0.48)\end{array}$ \\
\hline Domestic Banking Credit & $\begin{array}{c}-0.47 * * * \\
(-7.15)\end{array}$ & $\begin{array}{c}-0.33 * * * \\
(-8.16)\end{array}$ & $\begin{array}{c}-0.35 * * * \\
(-7.16)\end{array}$ & $\begin{array}{c}-0.34 * * * \\
(-10.48)\end{array}$ & $\begin{array}{c}-0.35^{* * *} \\
(-11.00)\end{array}$ & $\begin{array}{c}-0.53 * * * \\
(-3.07)\end{array}$ \\
\hline $\mathrm{PE} \times$ Parent $\mathrm{CFO}$ & $\begin{array}{c}0.57 \\
(0.43)\end{array}$ & $\begin{array}{c}0.23 \\
(0.97)\end{array}$ & $\begin{array}{c}0.21 \\
(0.59)\end{array}$ & $\begin{array}{c}0.34 \\
(1.17)\end{array}$ & $\begin{array}{c}0.38 \\
(1.50)\end{array}$ & $\begin{array}{c}-1.40 * * * \\
(-2.81)\end{array}$ \\
\hline $\mathrm{PE} \times$ Parent Ownership & $\begin{array}{c}-0.29 \\
(-0.80)\end{array}$ & $\begin{array}{c}0.05 \\
(0.69)\end{array}$ & $\begin{array}{c}-0.10 \\
(-0.80)\end{array}$ & $\begin{array}{l}0.17^{*} \\
(1.80)\end{array}$ & $\begin{array}{c}0.04 \\
(0.47)\end{array}$ & $\begin{array}{c}0.10 \\
(0.54)\end{array}$ \\
\hline PE $\times$ Domestic Banking Credit & $\begin{array}{c}1.83 * * * \\
(2.90)\end{array}$ & $\begin{array}{c}0.67 * * * \\
(5.67)\end{array}$ & $\begin{array}{c}0.65 * * * \\
(3.05)\end{array}$ & $\begin{array}{c}0.75 * * * \\
(6.71)\end{array}$ & $\begin{array}{c}0.76^{* * *} \\
(6.23)\end{array}$ & $\begin{array}{c}0.08 \\
(0.16)\end{array}$ \\
\hline Test $(\mathrm{PE} \times \mathrm{IE}):$ High $=$ Low & \multicolumn{2}{|c|}{$p$-Value: 0.001} & \multicolumn{2}{|c|}{$p$-Value: 0.040} & \multicolumn{2}{|c|}{$p$-Value: 0.099} \\
\hline $\mathrm{PE} \times$ Country Indicators & Yes & Yes & Yes & Yes & Yes & Yes \\
\hline $\mathrm{PE} \times$ Firm-level Internal Mechanisms & Yes & Yes & Yes & Yes & Yes & Yes \\
\hline MNC Indicators & Yes & Yes & Yes & Yes & Yes & Yes \\
\hline Country Pairs Indicators & Yes & Yes & Yes & Yes & Yes & Yes \\
\hline Industry Indicators & Yes & Yes & Yes & Yes & Yes & Yes \\
\hline SE Clustering (Country-Industry) & Yes & Yes & Yes & Yes & Yes & Yes \\
\hline \# Firm-Years & 4,088 & 28,075 & 12,380 & 19,783 & 27,557 & 4,606 \\
\hline Adj. R-Square & $17.0 \%$ & $12.9 \%$ & $13.9 \%$ & $12.9 \%$ & $12.9 \%$ & $19.1 \%$ \\
\hline
\end{tabular}




\section{TABLE 6}

\section{Investment Regressions by Location of Decision Rights}

This table presents the results from subsidiary-level regressions of asset growth on industry growth opportunities, the information environments in each country-industry-year, an interaction term between growth opportunities and the information environment and control variables. The regressions are partitioned into two groups based on the location of decision rights between the parent and the subsidiary. $P E$ is the price-to-earnings ratio of the country-industry-year of the subsidiary. $I E$ is the yearly quartile rank of our proxies for the information environment. Relative Size is an indicator variable that equals one if the subsidiary is above the median size (measured using total assets) relative to the other subsidiaries owned by the same parent firm. Management Team Composition is an indicator variable that equals one if the subsidiary's management team (i.e., all senior managers, C-suite executives in operations and R\&D, and board of directors) has more expatriates than the sample median. Expatriates are defined as employees whose nationality differs from the country where the subsidiary is domiciled. Operating Industry is an indicator variable that equals one if the parent and the subsidiary operate in the same industry (one-digit ICB code). All other variables are as defined above Table 4. All regressions include the fixed effects of each parent firm, parent-country subsidiary-country pair, and the subsidiary's ICB industry. The regressions also include interaction terms between each subsidiary-country indicator and PE. T-Statistics are reported in parentheses below the regression coefficients and we cluster standard errors at the country-industry level. $* * *, * *$, and $*$ denote statistical significance at the two tailed $1 \%, 5 \%$, and $10 \%$ levels.

\begin{tabular}{|c|c|c|c|c|c|c|c|}
\hline \multicolumn{8}{|c|}{ Dependent Variable: Asset Growth } \\
\hline \multirow{2}{*}{$\begin{array}{l}\text { Allocation of Decision Making } \\
\text { Rights btw. Parent and Sub: }\end{array}$} & \multirow{2}{*}{$\begin{array}{l}\text { Pr. } \\
\text { Sign }\end{array}$} & \multicolumn{2}{|c|}{ Relative Size } & \multicolumn{2}{|c|}{ Mgmt. Team Composition } & \multicolumn{2}{|c|}{ Operating Industry } \\
\hline & & $\begin{array}{c}\text { Low } \\
\text { involve }\end{array}$ & $\begin{array}{c}\text { High } \\
\text { involve }\end{array}$ & $\begin{array}{c}\text { Low } \\
\text { involve }\end{array}$ & $\begin{array}{l}\text { High } \\
\text { involve }\end{array}$ & $\begin{array}{c}\text { Low } \\
\text { involve }\end{array}$ & $\begin{array}{c}\text { High } \\
\text { involve }\end{array}$ \\
\hline $\mathrm{PE} \times \mathrm{IE}$ & $? /+$ & $\begin{array}{c}0.17 \\
(0.92)\end{array}$ & $\begin{array}{c}0.69 * * * \\
(3.02)\end{array}$ & $\begin{array}{c}0.23 \\
(1.12)\end{array}$ & $\begin{array}{c}0.77 * * * \\
(3.90)\end{array}$ & $\begin{array}{l}0.56^{* *} \\
(2.10)\end{array}$ & $\begin{array}{c}0.73 * * * \\
(3.23)\end{array}$ \\
\hline \multicolumn{2}{|l|}{ IE } & $\begin{array}{c}-0.16^{* *} \\
(-2.36)\end{array}$ & $\begin{array}{c}-0.16^{* * *} \\
(-2.74)\end{array}$ & $\begin{array}{c}-0.08 \\
(-1.29)\end{array}$ & $\begin{array}{c}-0.23 * * * \\
(-3.33)\end{array}$ & $\begin{array}{l}-0.14 * \\
(-1.94)\end{array}$ & $\begin{array}{c}-0.26^{* * *} \\
(-4.06)\end{array}$ \\
\hline \multicolumn{2}{|l|}{ ROA } & $\begin{array}{c}0.36^{* * *} \\
(5.59)\end{array}$ & $\begin{array}{c}0.26^{* * *} \\
(5.55)\end{array}$ & $\begin{array}{c}0.39^{* * *} \\
(6.18)\end{array}$ & $\begin{array}{c}0.30^{* * * *} \\
(5.74)\end{array}$ & $\begin{array}{c}0.33^{* * *} \\
(5.03)\end{array}$ & $\begin{array}{c}0.31 * * * \\
(6.21)\end{array}$ \\
\hline \multicolumn{2}{|l|}{ Log Assets } & $\begin{array}{c}-0.19 * * * \\
(-15.10)\end{array}$ & $\begin{array}{c}-0.18 * * * \\
(-22.11)\end{array}$ & $\begin{array}{c}-0.10^{* * * *} \\
(-10.15)\end{array}$ & $\begin{array}{c}-0.08^{* * *} \\
(-20.60)\end{array}$ & $\begin{array}{c}-0.08^{* * *} \\
(-17.18)\end{array}$ & $\begin{array}{c}-0.09^{* * *} \\
(-13.98)\end{array}$ \\
\hline \multicolumn{2}{|l|}{ Parent CFO } & $\begin{array}{c}0.19 \\
(1.59)\end{array}$ & $\begin{array}{l}0.23^{*} \\
(1.66)\end{array}$ & $\begin{array}{c}0.19 \\
(1.40)\end{array}$ & $\begin{array}{c}0.32 * * \\
(2.42)\end{array}$ & $\begin{array}{c}0.30^{* * *} \\
(2.88)\end{array}$ & $\begin{array}{l}0.25^{*} \\
(1.79)\end{array}$ \\
\hline \multicolumn{2}{|l|}{ Parent Ownership } & $\begin{array}{c}0.07 \\
(1.57)\end{array}$ & $\begin{array}{c}0.08 \\
(1.33)\end{array}$ & $\begin{array}{c}0.05 \\
(0.73)\end{array}$ & $\begin{array}{c}0.09^{* * *} \\
(2.62)\end{array}$ & $\begin{array}{c}0.13^{* * *} \\
(2.72)\end{array}$ & $\begin{array}{c}0.07 \\
(1.39)\end{array}$ \\
\hline \multicolumn{2}{|l|}{ Domestic Banking Credit } & $\begin{array}{c}-0.31 * * * \\
(-7.64)\end{array}$ & $\begin{array}{c}-0.37 * * * \\
(-8.13)\end{array}$ & $\begin{array}{c}-0.37 * * * \\
(-10.79)\end{array}$ & $\begin{array}{c}-0.39 * * * \\
(-6.79)\end{array}$ & $\begin{array}{c}-0.35 * * * \\
(-8.05)\end{array}$ & $\begin{array}{c}-0.36^{* * *} \\
(-10.38)\end{array}$ \\
\hline \multicolumn{2}{|l|}{$\mathrm{PE} \times$ Parent $\mathrm{CFO}$} & $\begin{array}{c}0.40 \\
(1.47)\end{array}$ & $\begin{array}{c}0.40 \\
(1.07)\end{array}$ & $\begin{array}{c}0.41 \\
(0.72)\end{array}$ & $\begin{array}{c}0.13 \\
(0.46)\end{array}$ & $\begin{array}{c}0.30 \\
(1.01)\end{array}$ & $\begin{array}{c}0.25 \\
(0.69)\end{array}$ \\
\hline \multicolumn{2}{|l|}{ PE $\times$ Parent Ownership } & $\begin{array}{l}-0.03 \\
(-0.24)\end{array}$ & $\begin{array}{c}0.04 \\
(0.32)\end{array}$ & $\begin{array}{c}0.15 \\
(0.91)\end{array}$ & $\begin{array}{c}0.04 \\
(0.46)\end{array}$ & $\begin{array}{l}-0.10 \\
(-0.85)\end{array}$ & $\begin{array}{l}0.19^{*} \\
(1.69)\end{array}$ \\
\hline \multicolumn{2}{|l|}{$\mathrm{PE} \times$ Domestic Banking Credit } & $\begin{array}{c}0.60 * * * \\
(4.75)\end{array}$ & $\begin{array}{c}0.66 * * * \\
(3.07)\end{array}$ & $\begin{array}{c}0.88 * * * \\
(5.44)\end{array}$ & $\begin{array}{c}0.83 * * * \\
(5.10)\end{array}$ & $\begin{array}{c}0.69 * * * \\
(3.83)\end{array}$ & $\begin{array}{c}0.87 * * * \\
(4.30)\end{array}$ \\
\hline \multicolumn{2}{|l|}{ Test $(\mathrm{PE} \times \mathrm{IE}):$ High $=$ Low } & \multicolumn{2}{|c|}{$p$-Value: 0.03} & \multicolumn{2}{|c|}{$p$-Value: 0.05} & \multicolumn{2}{|c|}{$p$-Value: 0.14} \\
\hline \multicolumn{2}{|c|}{$\mathrm{PE} \times$ Country Indicators } & Yes & Yes & Yes & Yes & Yes & Yes \\
\hline \multicolumn{2}{|c|}{$\mathrm{PE} \times$ Firm-level Internal Mechanisms } & Yes & Yes & Yes & Yes & Yes & Yes \\
\hline \multicolumn{2}{|c|}{ MNC Indicators } & Yes & Yes & Yes & Yes & Yes & Yes \\
\hline \multicolumn{2}{|l|}{ Country Pairs Indicators } & Yes & Yes & Yes & Yes & Yes & Yes \\
\hline \multicolumn{2}{|l|}{ Industry Indicators } & Yes & Yes & Yes & Yes & Yes & Yes \\
\hline \multicolumn{2}{|l|}{ SE Clustering (Country-Industry) } & Yes & Yes & Yes & Yes & Yes & Yes \\
\hline \multicolumn{2}{|l|}{ \# Firm-Years } & 15,476 & 16,461 & 11,147 & 20,790 & 16,283 & 15,880 \\
\hline \multicolumn{2}{|l|}{ Adj. R-Square } & $23.1 \%$ & $23.4 \%$ & $16.6 \%$ & $12.4 \%$ & $15.3 \%$ & $13.4 \%$ \\
\hline
\end{tabular}




\section{TABLE 7}

\section{Using IFRS as a Shock to the Information Environment}

This table presents the results from subsidiary-level regressions of asset growth on industry growth opportunities, indicator variables for IFRS-adopting countries and the post-IFRS adoption years, an interaction term between growth opportunities and the IFRS indicator variables and control variables. IFRS Country is an indicator variable for all countries adopting IFRS. IFRS Proxy is either (i) Post 2005, which is an indicator variable for the calendar years after mandatory IFRS adoption in 2005 or (ii) \%IFRS, which is the proportion of firms adopting IFRS before its mandatory requirement (obtained from Daske et al. 2008). Following mandatory IFRS adoption, \%IFRS is set equal to one for all observations. All other variables are as defined earlier (see Tables 3 and 4). T-Statistics are reported in parentheses below the regression coefficients and we cluster standard errors at the country-industry level. ***,**, and * denote statistical significance at the two tailed $1 \%, 5 \%$, and $10 \%$ levels.

\begin{tabular}{|c|c|c|c|}
\hline \multicolumn{4}{|c|}{ Dependent Variable: Asset Growth } \\
\hline \multirow[b]{2}{*}{ Variables } & \multirow[b]{2}{*}{ Predicted Sign } & \multicolumn{2}{|c|}{$\underline{\text { IFRS Proxy }}$} \\
\hline & & Post 2005 & $\% I F R S$ \\
\hline PE $\times$ IFRS Proxy & & $\begin{array}{c}-0.12 \\
(-1.33)\end{array}$ & $\begin{array}{l}-0.16^{*} \\
(-1.84)\end{array}$ \\
\hline PE $\times$ IFRS Country & & $\begin{array}{c}9.65 \\
(0.83)\end{array}$ & $\begin{array}{c}9.42 \\
(0.83)\end{array}$ \\
\hline PE $\times$ IFRS Proxy $\times$ IFRS Country & + & $\begin{array}{l}0.25^{*} \\
(1.86)\end{array}$ & $\begin{array}{c}0.33^{* * *} \\
(2.78)\end{array}$ \\
\hline IFRS Proxy $\times$ IFRS Country & & $\begin{array}{c}-0.08 * * \\
(-2.34)\end{array}$ & $\begin{array}{c}0.02 \\
(0.53)\end{array}$ \\
\hline IFRS Proxy & & $\begin{array}{c}0.01 \\
(0.45)\end{array}$ & $\begin{array}{c}0.04 \\
(1.45)\end{array}$ \\
\hline ROA & & $\begin{array}{c}0.32 * * * \\
(6.88)\end{array}$ & $\begin{array}{c}0.31 * * * \\
(7.23)\end{array}$ \\
\hline Log Assets & & $\begin{array}{c}-0.07 * * * \\
(-19.38)\end{array}$ & $\begin{array}{c}-0.07 * * * \\
(-23.01)\end{array}$ \\
\hline Parent CFO & & $\begin{array}{l}0.23 * * \\
(2.08)\end{array}$ & $\begin{array}{l}0.23 * * \\
(2.16)\end{array}$ \\
\hline Parent Ownership & & $\begin{array}{c}0.04 \\
(1.06)\end{array}$ & $\begin{array}{c}0.05 \\
(1.64)\end{array}$ \\
\hline Domestic Banking Credit & & $\begin{array}{c}-0.25 * * * \\
(-5.93)\end{array}$ & $\begin{array}{c}-0.47 * * * \\
(-10.00)\end{array}$ \\
\hline $\mathrm{PE} \times$ Parent $\mathrm{CFO}$ & & $\begin{array}{c}0.44 \\
(1.23)\end{array}$ & $\begin{array}{c}0.31 \\
(1.00)\end{array}$ \\
\hline $\mathrm{PE} \times$ Parent Ownership & & $\begin{array}{l}0.20 * * \\
(2.14)\end{array}$ & $\begin{array}{c}0.11 \\
(1.13)\end{array}$ \\
\hline PE $\times$ Domestic Banking Credit & & $\begin{array}{c}0.53 * * * \\
(3.35)\end{array}$ & $\begin{array}{c}0.44 * * * \\
(3.32)\end{array}$ \\
\hline $\mathrm{PE} \times$ Country Indicators & & Yes & Yes \\
\hline $\mathrm{PE} \times$ Firm-level Internal Mechanisms & & Yes & Yes \\
\hline MNC Indicators & & Yes & Yes \\
\hline Country Pairs Indicators & & Yes & Yes \\
\hline Industry Indicators & & Yes & Yes \\
\hline SE Clustering (Country-Industry) & & Yes & Yes \\
\hline \# Firm-Years & & 28,029 & 32,163 \\
\hline Adj. R-Square & & $13.4 \%$ & $13.3 \%$ \\
\hline
\end{tabular}




\section{TABLE 8}

\section{Using Domestic Subsidiaries and Foreign Stand-Alone Firms as Benchmark Groups}

This table presents the results from subsidiary-level regressions of asset growth on industry growth opportunities, the information environments in each country-industry-year, an interaction term between growth opportunities and the information environment and control variables. $P E$ is the price-to-earnings ratio of the country-industry-year of the subsidiary. $I E$ is the yearly quartile rank of our proxies for the information environment. We proxy for $I E$ using the median number of analysts following firms in the country-industry-year (Analyst Coverage), the median number of press articles about firms in the country-industry-year (Press Coverage), and -1 times the absolute value of the ratio of accruals scaled by the cash flow from operations for the median firm in each country-industry-year (Earnings Transparency). The regressions are estimated using three samples: 1) the foreign subsidiaries of MNCs, 2) the domestic subsidiaries of MNCs, and 3) foreign standalone firms that are matched to foreign subsidiaries on size, industry, country, and year. Domestic subsidiaries of MNCs are subsidiaries located in the same country as the parent. See Tables 3-5 for all variable definitions. T-Statistics are reported in parentheses below the regression coefficients and we cluster standard errors at the country-industry level. ${ }^{* *},{ }^{* *}$, and $*$ denote statistical significance at the two tailed $1 \%, 5 \%$, and $10 \%$ levels.

\begin{tabular}{|c|c|c|c|c|}
\hline \multicolumn{5}{|c|}{ Dependent Variable: Asset Growth } \\
\hline Benchmark Samples: & $\begin{array}{l}\text { Pr. } \\
\text { Sign }\end{array}$ & $\begin{array}{c}\text { Foreign } \\
\text { Subsidiaries } \\
\text { (Table 4) }\end{array}$ & $\begin{array}{l}\text { Domestic } \\
\text { Subsidiaries }\end{array}$ & $\begin{array}{l}\text { Matched Foreign } \\
\text { Standalone Firms }\end{array}$ \\
\hline $\mathrm{PE} \times \mathrm{IE}$ & $+/ 0 / 0$ & $\begin{array}{c}0.52^{* * * *} \\
(3.25)\end{array}$ & $\begin{array}{l}-0.13 \\
(-0.73)\end{array}$ & $\begin{array}{l}-0.14 \\
(-0.57)\end{array}$ \\
\hline IE & & $\begin{array}{c}-0.18 * * * \\
(-3.52)\end{array}$ & $\begin{array}{l}-0.04 \\
(-0.95)\end{array}$ & $\begin{array}{c}0.07 \\
(0.98)\end{array}$ \\
\hline ROA & & $\begin{array}{c}0.31 * * * \\
(7.21)\end{array}$ & $\begin{array}{c}0.57 * * * \\
(9.28)\end{array}$ & $\begin{array}{c}0.36^{* * * *} \\
(8.36)\end{array}$ \\
\hline Log Assets & & $\begin{array}{c}-0.07 * * * \\
(-22.40)\end{array}$ & $\begin{array}{c}-0.04 * * * \\
(-12.08)\end{array}$ & $\begin{array}{l}0.01 * * \\
(2.04)\end{array}$ \\
\hline Parent CFO & & $\begin{array}{c}0.27 * * * \\
(2.72)\end{array}$ & $\begin{array}{c}0.61^{* * *} \\
(6.71)\end{array}$ & N/A \\
\hline Parent Ownership & & $\begin{array}{l}0.06 * * \\
(2.06)\end{array}$ & $\begin{array}{c}0.04 \\
(1.53)\end{array}$ & $\mathrm{N} / \mathrm{A}$ \\
\hline Domestic Banking Credit & & $\begin{array}{c}-0.35 * * * \\
(-11.12)\end{array}$ & $\begin{array}{c}-0.39 * * * \\
(-9.35)\end{array}$ & $\begin{array}{l}(0.07) \\
(-1.29)\end{array}$ \\
\hline $\mathrm{PE} \times$ Parent $\mathrm{CFO}$ & & $\begin{array}{c}0.25 \\
(1.11)\end{array}$ & $\begin{array}{c}0.00 \\
(-0.01)\end{array}$ & N/A \\
\hline PE $\times$ Parent Ownership & & $\begin{array}{c}0.06 \\
(0.80)\end{array}$ & $\begin{array}{l}0.16^{* *} \\
(2.10)\end{array}$ & N/A \\
\hline $\mathrm{PE} \times$ Domestic Banking Credit & & $\begin{array}{c}0.71 * * * \\
(6.75)\end{array}$ & $\begin{array}{c}0.92 * * * \\
(5.51)\end{array}$ & $\begin{array}{c}0.74 * * * \\
(3.29)\end{array}$ \\
\hline Test $(\mathrm{PE} \times \mathrm{IE})$ : Control Sample $=$ Treatment Sample & & & $p$-Value: 0.007 & $p$-Value: 0.009 \\
\hline $\mathrm{PE} \times$ Country Indicators & & Yes & Yes & Yes \\
\hline $\mathrm{PE} \times$ Firm-level internal mechanisms & & Yes & Yes & Yes \\
\hline MNC Indicators & & Yes & Yes & $\mathrm{N} / \mathrm{A}$ \\
\hline Country Pairs Indicators & & Yes & Yes & $\mathrm{N} / \mathrm{A}$ \\
\hline Country Indicators & & $\mathrm{N} / \mathrm{A}$ & $\mathrm{N} / \mathrm{A}$ & Yes \\
\hline Industry Indicators & & Yes & Yes & Yes \\
\hline SE Clustering (Country-Industry) & & Yes & Yes & Yes \\
\hline \# Firm-Years & & 32,163 & 33,759 & 31,957 \\
\hline Adj. R-Square & & $13.2 \%$ & $12.0 \%$ & $9.9 \%$ \\
\hline
\end{tabular}

